\title{
Article \\ Development and Yield Traits Indicate That the Constitutive Wound Response Phenotype of Prosystemin Overexpressing Tomato Plants Entails No Fitness Penalty
}

\author{
Mariela Luna-Martínez ${ }^{1}$, Norma Martínez-Gallardo ${ }^{2}$, Kena Casarrubias-Castillo ${ }^{3}$, Simona M. Monti ${ }^{4}$ (D) \\ Mariangela Coppola ${ }^{5}$, Rosa Rao ${ }^{5}$ id and John P. Délano-Frier ${ }^{2, *(D)}$
}

check for updates

Citation: Luna-Martínez, M.; Martínez-Gallardo, N.

Casarrubias-Castillo, K.; Monti, S.M.; Coppola, M.; Rao, R.; Délano-Frier, J.P. Development and Yield Traits Indicate That the Constitutive Wound Response Phenotype of Prosystemin Overexpressing Tomato Plants Entails No Fitness Penalty. Agronomy 2021, 11, 1148. https://doi.org/10.3390/ agronomy11061148

Academic Editors: Muhammad Amjad Nawaz, Kirill S. Golokhvast, Gyuhwa Chung, Aristidis

M. Tsatsakis and Michael N. Antoniou

Received: 9 May 2021

Accepted: 31 May 2021

Published: 3 June 2021

Publisher's Note: MDPI stays neutral with regard to jurisdictional claims in published maps and institutional affiliations.

Copyright: (c) 2021 by the authors. Licensee MDPI, Basel, Switzerland. This article is an open access article distributed under the terms and conditions of the Creative Commons Attribution (CC BY) license (https:// creativecommons.org/licenses/by/ $4.0 /)$
1 Departamento de Fitotecnia, Universidad Autónoma Chapingo, Carretera Federal Km 38.5 México-Texcoco, 56230 Texcoco, Mexico; merriluna@hotmail.com

2 Unidad de Biotecnología e Ingeniería Genética de Plantas, Centro de Investigación y de Estudios Avanzados del IPN, Km 9.6 del Libramiento Norte Carretera Irapuato-León, 36500 Irapuato, Mexico; norma.martinez@cinvestav.mx

3 Centro Universitario de Ciencias Biológicas y Agropecuarias, Universidad de Guadalajara, Camino Ramón Padilla Sánchez 2100 Nextipac, 45200 Zapopan, Mexico; kena.casarrubias@academicos.udg.mx

4 Institute of Biostructures and Bioimaging, CNR, via Mezzocannone 16, I-80134 Naples, Italy; marmonti@unina.it

5 Dipartimento di Agraria, Universita degli Studi di Napoli Federico II, Via Università 100, 80055 Portici, Italy; mariangela.coppola@unina.it (M.C.); rao@unina.it (R.R.)

* Correspondence: john.delano@cinvestav.mx; Tel.: +52-462-6239636 or +52-462-6239600

Abstract: Systemin is a peptide hormone that regulates the wound response in tomato plants. Consequently, the overexpression of its prosystemin (ProSys) precursor protein leads to a resourcedemanding constitutive activation of tomato's wound-response. According to the growth vs. defense resource allocation premise, ProSys overexpression should negatively affect the physiological fitness of tomato plants. The present study was performed to explore why the opposite effect was steadily observed, instead. It was based on the premise that a better understanding of this unexpected outcome could help establish improved wound and related defense responses without negatively affecting crop productivity. To this effect, an experimental strategy was deployed to measure various physiological, biochemical and molecular parameters associated with either development, productivity, defense or in combination in untransformed (WT) and ProSys overexpressing (ProSysOE) tomato plants. Thus, the chlorophyll fluorescence data obtained from plants grown under greenhouse experiments indicated that photosynthetic performance was not affected in ProSys-OE plants which also grew 7-14\% taller than WT plants. Moreover, they showed accelerated flowering and yielded fruits of increased size (7-16\% taller and wider) and weight (16-58\% heavier), with modified fruit quality in terms of firmness (28\% higher), titratable acidity (27-32\% higher) and chemical composition. These findings suggest two complementary possibilities: (i) systemin is able to modulate both the wound response and plant development through the activation of jasmonic acid biosynthesis and signaling, and (ii) ProSys, an intrinsically disordered protein, acts as a signaling hub to regulate development and defense programs. These results shed light on the understanding of this plant regulatory mechanism and further suggest that systemin/ProSys-based regulation is central to control the defense-development balance in tomato. This knowledge could eventually lead to improved and more environmentally sound agricultural production practices.

Keywords: fitness penalties; growth-defense resource allocation; intrinsically disordered proteins; jasmonic acid; Solanum lycopersicum

\section{Introduction}

Systemin (Sys) is a biologically active 18-amino acid (aa) peptide, presumably released by phytaspases-mediated enzymatic processing of prosystemin (ProSys), its precursor 
protein, also known to be an intrinsically disordered protein (IDP) [1-5]. Sys was isolated from tomato leaves based on its capacity to activate the octadecanoid pathway and the biosynthesis of jasmonic acid (JA) and its conjugates, leading to the subsequent activation of the wound response through the induction of several defense genes/proteins, such as proteinase inhibitors $[1,6]$. Sys was also hailed as the long-sought mobile signal responsible for the activation of systemic wound responses. Subsequent experimental evidence revealed, however, that it mostly acts locally at the wounding site, amplifying the synthesis of jasmonates (JAs), recognized as prominent systemic signals able to activate defense-related responses in distal tissues $[7,8]$. Local Sys activity is triggered by its interaction with a cell surface receptor, SYR1, an LRR-RLK receptor that closely resembles pattern recognition receptors [9]. Consequently, Sys activates early cellular responses similar to those prompted by microbe-associated molecular patterns, such as a rapid and temporary rise in cytosolic calcium, apoplastic alkalization, plasma membrane depolarization, generation of ethylene (ET) and reactive oxygen species and extensively altered phosphorylation protein patterns [10-13]. Apart from tomato, Sys homologs have only been identified in a handful of plant species belonging to the Solaneae sub-tribe such as, potato, bell pepper and nightshade [1]. However, a large body of experimental evidence has gradually revealed the ubiquity of plant defense activating peptides, including hydroxyproline-rich systemin glycopeptides, plant elicitor peptides, Zea mays immune signaling peptide 1, PAMP-induced peptides, IDA-like peptides, rapid alkalinization factors, phytosulfokines and inceptins [14].

ProSys is known to accumulate in tomato cells in response to wounding, insect herbivory or exogenous treatment with methyl jasmonate (MeJA) [15]. Evidence gathered via the generation of transgenic tomato plants constitutively expressing the ProSys precursor, or unable to do so by anti-sense silencing, further confirmed not only the role of Sys in orchestrating resistance against chewing insect herbivores, necrotrophic phytopathogenic fungi and virus [3,16-20], but also in the modulation of bioactive volatile organic compounds emission to promote indirect defense responses through the attraction of parasitoid wasps [21,22]. They were also found to have increased tolerance to moderate salt stress $[23,24]$. Further reports demonstrated that the application of exogenous Sys to tomato plants significantly enhanced direct and indirect defense mechanisms against chewing insect pests and fungal pathogens $[22,25]$.

Numerous external and internal factors compel plants to prioritize their resource allocation between growth and defense. Appropriate exercise of this vital phenomenon ensures plant survival and reproduction and optimizes fitness under constantly fluctuating ambient conditions in which contact with a variety of pathogens and insect herbivores having different life styles and infection strategies is inevitable [26,27]. Mounting a defense response to counter these aggressors usually involves a high demand for resources that is thought to negatively impact growth. Impaired growth may result either from reduced photosynthetic activity/efficiency, from funneling away vital resources for defense purposes, or both $[28,29]$. Initially observed in plant-insect interactions within a forestry context, the 'growth-defense trade-off' hypothesis proposing that limited plants resources can be channeled either to growth or defense [30,31], was supported by several studies that demonstrated the fitness costs associated with defense [32-36]. The effect was particularly evident when JA- or salicylic acid -regulated defense responses were induced artificially in the absence of biotic aggressors or by using excessive, non-physiological doses of defenseresponse inducers [37-41], or under stress conditions restricting energy production [42,43]. These physiological costs were associated with the re-assignation of carbon and nitrogen reserves to the biosynthesis of defensive metabolites or proteins. This shift was found to require profound transcriptional reprogramming leading to altered protein synthesis in addition to the promotion of folding and secretion mechanisms designed to support the defense effort against pathogens or herbivores [28]. More recently, this relatively straightforward scenario has been substituted by proposals involving more complex mechanisms relying on active hormonal cross-talk able to impact multiple signaling networks that 
adjust growth rates in response to the activation of defense responses [28,29,35,36,44-47]. In this respect, JAs have been identified as central players of a complex regulatory hub that controls metabolic reprogramming leading to suppressed growth in response to various adverse environmental conditions and biotic stresses, such as insect herbivory and wounding [28,46-49].

Within this context, a previous report investigated the cost of mounting a constitutive wound-related defense response designed to deter chewing insect herbivory in tomato plants [50]. It utilized transgenic tomato plants able to constitutively express the ProSys precursor protein [3] from which the 18-aa Sys peptide is presumably released in order to strongly activate the transcription of numerous defense genes via JA $[2,3,19,51,52]$. The data obtained showed that the continuous activation of defensive traits in these plants was physiologically costly, and negatively affected the growth and reproductive fitness of tomato plants. Possibly linked to this outcome were the significantly lower $\mathrm{CO}_{2}$ assimilation and stomatal conductance rates, previously associated with the exogenous application of JA $[53,54]$, that presumably led to disrupted source-sink relationships. Other phenotypes, such as a lowered number of seeds per fruit and reduced protein diversity due to an overabundance of defensive proteins in fruits were a reflection of lower reproduction fitness. The present study describes results that contradict those reported previously by these workers. Contrary to their findings, tomato ProSys over-expressing plants, although having slight morphological differences but still showing the typical constitutive wound-response phenotype characterized by an over-representation of wound-responsive proteins and genes, were found to greatly outperform wild-type (WT) untransformed plants in several reproductive fitness traits. These consisted of increased fruit size and weight, in addition to modified fruit quality in terms of firmness, titratable acidity and chemical composition.

Two hypothetical and perhaps complementary scenarios are proposed to explain the results obtained. The first postulates that, in addition to the wound response, Sys is able to positively modulate plant development through the activation of JA biosynthesis and signaling. The second, that the IDP nature of the ProSys precursor acts as a signaling hub to regulate defense- and development-regulated programs. The findings further imply that the multiple regulatory capacity of systemin/ProSys complex is central to control the defense-development balance in plants. These proposals are further discussed in terms of established and emerging experimental evidence.

A better understanding of this regulatory system has the potential to be employed to improve agricultural practices and crop yields. This objective could be accomplished by increasing the defensive capability of plants against biotic stressors and, perhaps, by promoting their association with beneficial plant growth-promoting microorganisms, without negatively affecting productivity and the surrounding environment.

\section{Materials and Methods}

All experiments were performed in a high security greenhouse of the "Centro de Investigación y de Estudios Avanzados (Cinvestav), unidad Irapuato". This research center is located in the municipality of Irapuato, in the state of Guanajuato, Mexico $\left(101^{\circ} 20^{\prime} 48^{\prime \prime} \mathrm{W}\right.$ and $20^{\circ} 40^{\prime} 18^{\prime \prime} \mathrm{N}$; UTM 14Q257063E2292947N). Its average height above sea level is $1730 \mathrm{~m}$.

\subsection{Plant Material}

Seeds of wild-type (WT) tomato (Solanum lycopersicum L. cv. Castlemart) were supplied by the Tomato Genetic Resource Center at the University of California, Davis, (Davis, CA, USA) while those of the prosystemin over-expressing transgenic plants (ProSys-OE, in the cv. Castlemart genetic background) were donated by Dr. Gregg Howe (Michigan State University, East Lansing, MI, USA). The seeds were surface-sterilized by soaking in a $70 \%$ ethanol solution for $60 \mathrm{~s}$, then in a $20 \%$ household bleach solution $(5 \% \mathrm{w} / \mathrm{v}$ sodium hypochlorite) for $5 \mathrm{~min}$ and rinsed three times with sterile water. All seeds were germinated in a conditioned growth chamber, kept at $21^{\circ} \mathrm{C}$, in 60 -well trays containing a sterile soil mixture constituted by equal parts of sand and loam which was autoclaved six 
times. Two-week-old seedlings were transplanted to $5 \mathrm{~L}$ pots (one plant per pot, fifteen plants per genotype) containing a sterilized soil mixture containing three parts Sunshine Mix (Sun-Gro Horticulture, Bellevue, WA, USA), one part loam, two parts mulch, one part vermiculite (Sun-Gro Horticulture) and one part perlite (Termolita S.A., Nuevo León, México). All pots were distributed randomly in the greenhouse. They were cultivated in the spring-summer of 2019. The temperature and relative humidity inside the greenhouse were not controlled. They reflected the ambient conditions characteristic of this season in this region of central Mexico (i.e., maximum and minimum average temperatures of $32{ }^{\circ} \mathrm{C}$ and $15{ }^{\circ} \mathrm{C}$, respectively, and maximum and minimum average relative humidity of 44 and 76\%, respectively; Weather Atlas, Yu Media Group d.o.o.). Sun-light intensity was reduced with a 50\% shade cloth (Wellco Industries Inc, Corona, CA, USA).

Following optimized procedures for greenhouse tomato cultivation under these conditions (Hernández-Razo A, personal communication), the plants were watered every second day for the first two weeks and then daily for the rest of the growth cycle. The plants received a weekly application of a foliar fertilizer (20N:30P:10K + minor nutrients; Agroquímicos Rivas S.A. de C.V; Celaya, Gto., Mexico) at a concentration of $10 \mathrm{~g} / \mathrm{L}$ during vegetative growth and at $5 \mathrm{~g} / \mathrm{L}$ during the reproductive phase. $\mathrm{A} \mathrm{Ca}^{2+}$ supplement was also applied to the foliage on a weekly basis at a concentration of $5 \mathrm{~mL} / \mathrm{L}$ (POLIQUEL Calcio; UPL Agro México; Mexico City, México).

\subsection{Evaluation of Plants during Vegetative and Reproductive Growth}

Ten plants of WT and ProSys-OE plants, respectively, were regularly examined, using non-destructive tests, to evaluate diverse growth-related parameters. Plant height, stem diameter, leaf number, total leaf area, and bud and flower number were determined. Plant height was measured with a flexometer, the stem diameter with a Vernier caliper, whereas leaf area was determined using ImageJ image analysis software (imagej.nih.gov / ij/download/ (accessed on 20 March 2021)). Chlorophyll fluorescence/photochemical efficiency of the PSII photosystem was similarly measured, as the Fv/Fm ratio, at 8 a.m. and 6 p.m. using a portable device (Pocket PEA Chlorophyll Fluorimeter; Hansatech Instruments; Norfolk, England). The measurements were performed in completely expanded adult leaves, positioned third from bottom to top. The chlorophyll content index (CCI) was determined in one of the three topmost youngest leaves of the plants. It was measured from the middle part of the leaves employing an OPTI-SCIENCESCCM 200 plus chlorophyll meter (Opti-Sciences, Inc.; Hudson, NH, USA). This apparatus calculates the CCI which is the ratio of percent transmission at 931 and $653 \mathrm{~nm}$ through a leaf sample [55]. All CCI measurements were determined at midday. All above measurements were performed weekly, starting from the third-week after transplant until the last of three fruit harvests. The phenology of each genotype was described in terms of days post-transplant (dpt). The temporality of reproductive pheno-phases from flower budding to mature fruits was recorded, as well.

\subsection{Evaluation of Fruit Quality}

Ten fruits per plant per genotype were examined once they reached physiological maturity or the red ripening stage. This started approximately at $68 \mathrm{dpt}$ for both genotypes and was extended to three harvesting stages. Several fruit parameters were measured. Fruits were weighed on a portable balance (Ohaus CS200; OHAUS Latin America, Mexico City, Mexico). Fruit length and width, in $\mathrm{cm}$, were recorded with a Vernier caliper. Total soluble solids (TSS) contents were measured using a hand-held digital refractometer (ATAGO PAL-1 Pocket, 0-32\%; Tokyo, Japan). Readings were reported as degrees Brix. Fruit color was determined on the fruit's epidermis at its equatorial plane by means of a SP-62 portable sphere spectrophotometer (X-Rite Inc., Grand Rapids, MI, USA). The CIE $1976\left(L^{*} a^{*} b^{*}\right)$ color coordinates were defined [56]. In the $L^{*} a^{*} b^{*}$ color space, $L^{*}$ indicates lightness and $a^{*}$ and $b^{*}$ are chromaticity coordinates. $a^{*}$ and $b^{*}$ are color directions: $+a^{*}$ is the red axis, $-a^{\prime}$ is the green axis, $+b^{*}$ is the yellow axis and $-b^{*}$ is the blue axis. From 
them, the chromaticity values $\left(\mathrm{C}^{*}=[\mathrm{a} 2+\mathrm{b} 2] 1 / 2\right)$ and tonality angle, $\mathrm{H}(\arctan -1(\mathrm{~b} / \mathrm{a}))$ were assessed.

Fruit firmness, an important index of fruit ripeness and quality, was determined using a Chatillon 25 Lbf penetrometer (AMETEK Sensors, Test \& Calibration, Elancourt, France) using a $7 \mathrm{~mm}$ conical tip. Three measurements per fruit were done, at the central plane and at both the upper and lower edges. Titratable acidity was calculated according to the AOAC 942.15 method [57]. Seed counts were performed in very large, large, small and very small fruits.

\subsection{Non-Structural Carbohydrate Content in Fruits}

Fruit soluble nonstructural carbohydrates (NSCs; glucose + fructose + sucrose) were determined using an enzymatic coupling method (Boehringer Mannheim/R-Biopharm, Darmstadt, Germany) as described previously [58,59] with minor modifications, such as its adaptation to a micro-plate format. Briefly, invertase, hexokinase and phosphoglucose isomerase were utilized in a step-wise manner to produce glucose-6P as a final product, which was subsequently used as substrate by glucose-6P dehydrogenase to generate 6phosphogluconate and NADPH, subsequently measured at $340 \mathrm{~nm}$. Exact quantification of soluble NSCs is based on a 1:1 hexose:NADPH stoichiometry. Insoluble starch, hydrolyzed to free glucose by a mixture of two $\alpha$-amylases and one amyloglucosidase, was quantified on the basis of the glucose generated, as above.

\subsection{Targeted Fruit Metabolomic Analysis}

The pulp of ten fruits obtained from different plants was flash-frozen in liquid $\mathrm{N}_{2}$ and ground to a fine powder with a mortar and pestle. Next, $1 \mathrm{~g}$ of the frozen ground tissue was extracted with $10 \mathrm{~mL}$ of methanol in $2 \mathrm{~mL}$ Falcon tubes. The mixtures were sonicated for $30 \mathrm{~min}$ and the subsequent extraction proceeded by constant stirring at $200 \mathrm{rpm}$ for $24 \mathrm{~h}$ at room temperature. The fruit extracts (FEs) were filtered through Whatman \#41 filter paper directly into amber glass vials which were subsequently sealed with a plastic film (Parafilm; Bemis North America, Neenah, WI, USA) and stored at $4{ }^{\circ} \mathrm{C}$ until analyzed. A targeted metabolomic analysis of the FEs was performed by GC-MS using a DB1MS UI capillary column $(60 \mu \mathrm{m} \times 250 \mu \mathrm{m} \times 0.25 \mu \mathrm{m}$; Agilent Technologies, Santa Clara, CA, USA) fitted to a 7890A gas chromatograph coupled to a selective mass detector (Agilent Technologies) as described before [60]. Compound metabolite identification was possible using the deconvolution AMDIS program (National Institute of Standards and Technology, NIST; Gaithersburg, MD, USA) and the NIST MS Database, search version 2.0. Three technical replicates per FE were included in the analysis.

\subsection{Extraction of Total RNA, cDNA Preparation and qPCR Analysis}

The RNA extraction procedure was performed as described previously [61]. Briefly, total RNA was extracted from frozen root and leaf tissues using a modified method based the use of the Trizol reagent (Invitrogen, Carlsbad, CA, USA). Total RNA was subsequently reverse transcribed to generate the first-strand cDNA using an oligo dT20 primer and 200 units of SuperScript II reverse transcriptase (Invitrogen). The cDNA was used for the qRT-PCR assays which were performed using SYBR Green detection chemistry in a CFX96 Touch Real-Time PCR Detection System (Bio-Rad, Hercules, CA, USA). Quantitative gene expression by real-time PCR was performed in triplicate using specific primers (Table S1), whose sequence was based on cDNA sequences derived from the tomato genome (Sol Genomics Network; Boyce Thompson Institute for Plant Research, Ithaca, NY, USA) [62]. The expression of a battery of selected genes was calculated using the $2^{-\Delta C t}$ method [63]. Transcript abundance data were normalized against the average transcript abundance of two reference genes: TIP41 and SAND [64]. Values reported were obtained using mRNA extracted from a single pooled sample prepared by separately combining the roots and leaves of ten adult plants that had reached a late vegetative development stage, prior to flowering. 


\subsection{Statistical Analysis}

Data were analyzed by one-way ANOVA. For multiple comparison of the means, Tukey honest significant difference (HSD) tests were applied with a confidence interval of $95 \%$. All tests were conducted using the Minitab 15 statistical software package (Minitab Inc., State College, PA, USA). Differences at $p<0.05$ were considered as statistically significant.

\section{Results}

\subsection{Plant Growth Rate, Onset of Flowering and Time for Full Fruit Maturation}

Untransformed WT plants grew more rapidly than ProSys OE plants in the first two weeks after transplanting (Figure 1). However, starting from $18 \mathrm{dpt}$, the ProSys-OE plants became consistently higher and eventually equaled WT plants in total leaf area and stem diameter at maturity (Table 1). However, leaf number remained significantly lower in ProSys-OE plants. No difference in the number of buds and flowers per plants was observed (Table 1). However, the first flower buds were observed in ProSys-OE plants at $20 \mathrm{dpt}$ and flower anthesis started at $32 \mathrm{dpt}$, two days before than WT plants (Figure 2). Fruit formation for both plant genotypes started ca. $69 \mathrm{dpt}$ and full maturation of the fruit cluster was reached ca. $36 \mathrm{~d}$ later.

\section{WT}
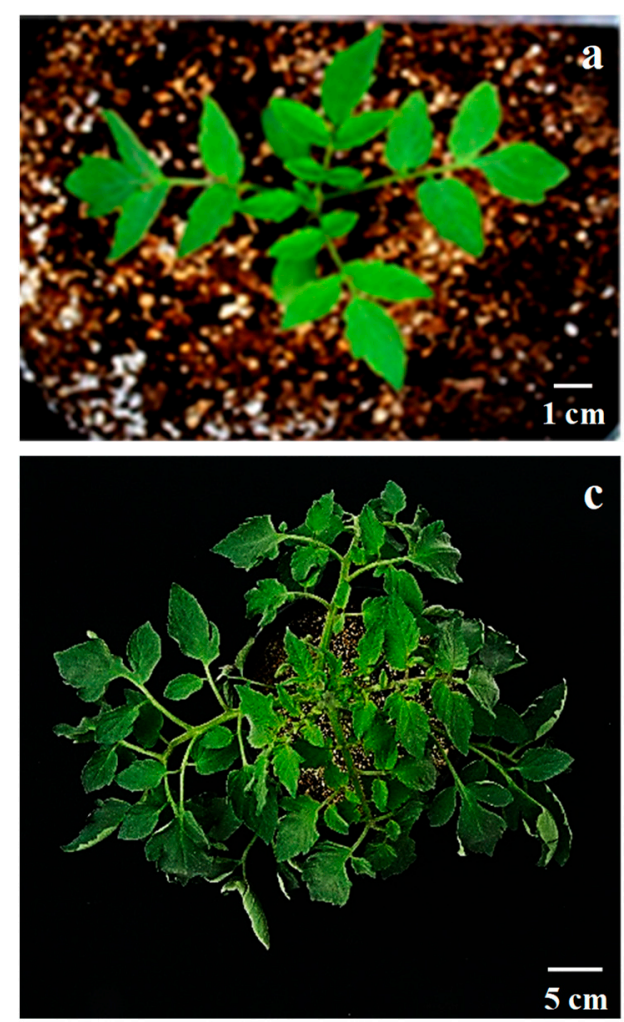

\section{ProSys OE}
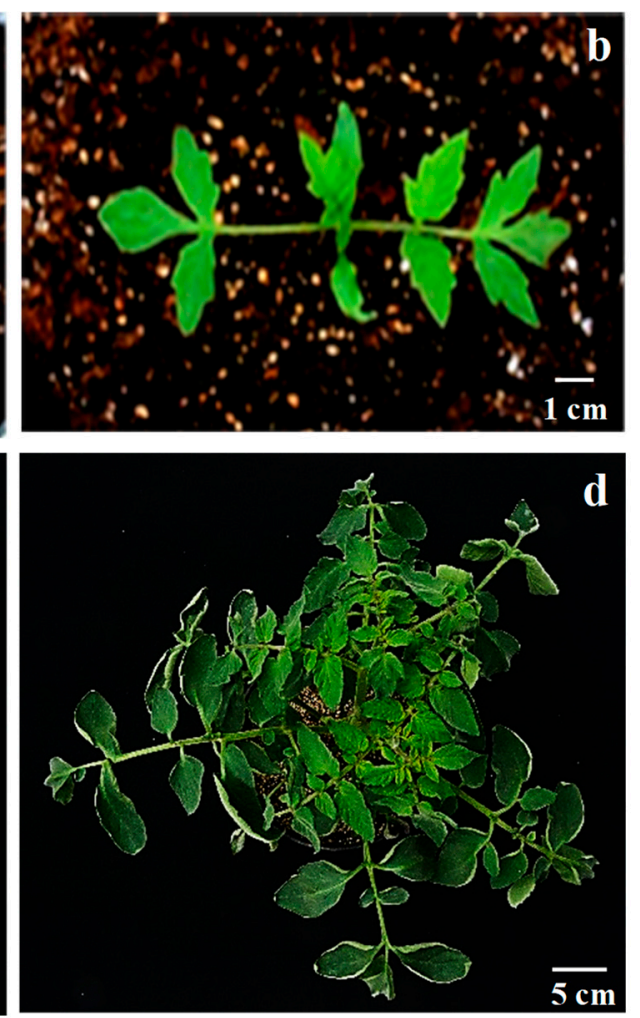

Figure 1. Growth and morphology of prosystemin overexpressing tomato plants. Compared to (a) wild-type (WT) untransformed tomato plants, (b) plants overexpressing the prosystemin (ProSys-OE) precursor of the systemin peptide hormone had a retarded growth at early developing stages (the images show plants 3 days post transplantation (dpt) into pots). In older plants, recorded $33 \mathrm{dpt}$, (c) WT plants were shorter, had a lower number of leaves and were compacter and morphologically different to (d) ProSys-OE plants. 
Table 1. Vegetative and reproductive growth parameters in wild-type (WT) and prosystemin overexpressing (ProSys OE) tomato plants. Six plant development- and reproductive-related attributes were measured in WT untransformed tomato plants and in ProSys-OE plants overexpressing the ProSys precursor protein of the systemin peptide hormone. Parameter quantification was performed in plants at 3,18 and 33 days post-transplantation (dpt) of seedlings to $5 \mathrm{~L}$ plant pots.

\begin{tabular}{|c|c|c|c|c|c|c|}
\hline \multirow{2}{*}{ Genotype } & \multicolumn{6}{|c|}{$3 \mathrm{dpt}$} \\
\hline & $\mathbf{H}^{1}$ & SD & LN & LA & BN & FN \\
\hline WT & $4.84 \pm 0.16 \mathrm{a}$ & ${ }^{2} 0.55 \pm 0.02 \mathrm{a}$ & $4.40 \pm 0.16 \mathrm{a}$ & $44.3 \pm 2 \mathrm{a}$ & - & - \\
\hline \multirow[t]{2}{*}{ ProSys-OE } & $5.39 \pm 0.2 \mathrm{a}$ & $0.43 \pm 0.02 \mathrm{~b}$ & $3.0 \pm 0.1 \mathrm{~b}$ & $20.6 \pm 2 b$ & - & - \\
\hline & \multicolumn{6}{|c|}{$18 \mathrm{dpt}$} \\
\hline WT & $15.6 \pm 0.42 b$ & $0.84 \pm 0.02 \mathrm{a}$ & $8.6 \pm 0.4 \mathrm{a}$ & $180.4 \pm 5 \mathrm{a}$ & - & - \\
\hline \multirow[t]{2}{*}{ ProSys-OE } & $17.9 \pm 0.31 \mathrm{a}$ & $0.71 \pm 0.02 b$ & $7.4 \pm 0.16 b$ & $108.3 \pm 7 b$ & - & - \\
\hline & \multicolumn{6}{|c|}{$33 \mathrm{dpt}$} \\
\hline WT & $37.6 \pm 1.0 \mathrm{~b}$ & $1.3 \pm 0.02 \mathrm{a}$ & $16.8 \pm 0.88 \mathrm{a}$ & $735.7 \pm 16 a$ & $2.44 \pm 0.41 \mathrm{a}$ & $12.67 \pm 1.63 \mathrm{a}$ \\
\hline ProSys-OE & $40.4 \pm 0.82 \mathrm{a}$ & $1.4 \pm 0.03 \mathrm{a}$ & $13.3 \pm 0.63 b$ & $698.4 \pm 20 \mathrm{a}$ & $2.67 \pm 0.61 \mathrm{a}$ & $12.87 \pm 0.88 \mathrm{a}$ \\
\hline
\end{tabular}

${ }^{1} \mathrm{H}=$ plant height; $\mathrm{SD}$ = stem diameter; $\mathrm{LN}=$ leaf number; $\mathrm{LA}$ = total leaf area, $\mathrm{BN}=$ bud number, FN, flower number. ${ }^{2}$ Numbers followed by different letters represent statistically significant values (Tukey test, $p \leq 0.05$ ).

WT

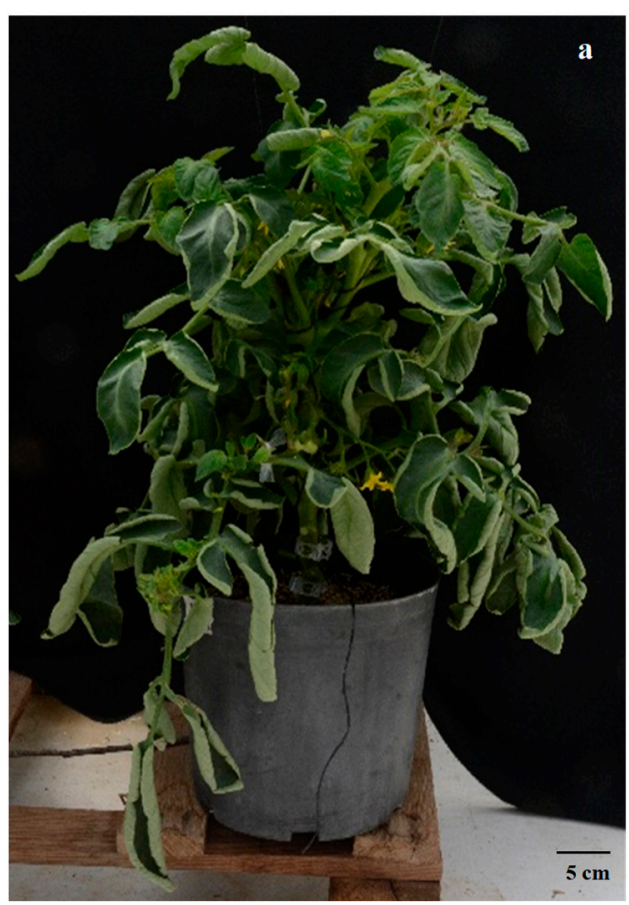

ProSys OE

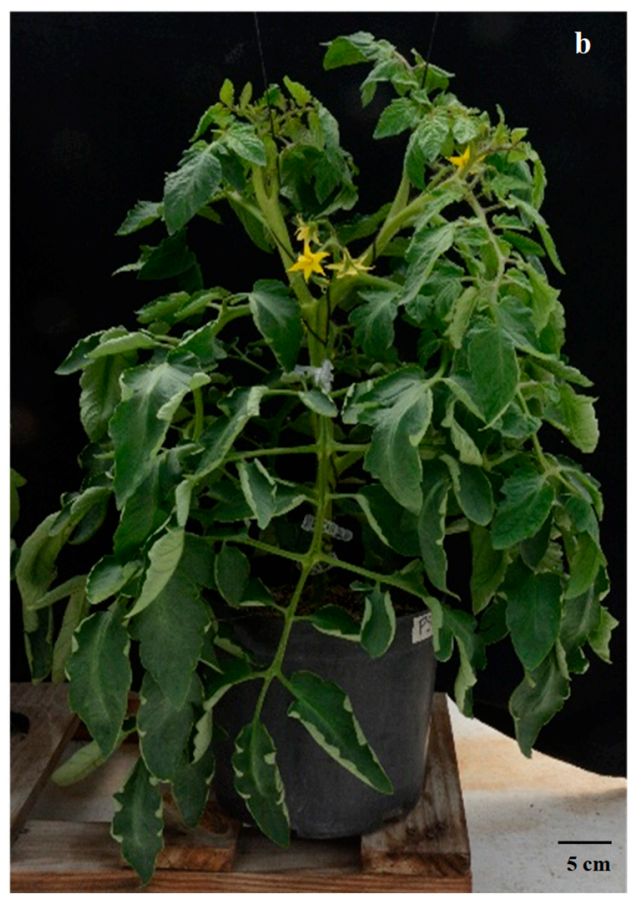

Figure 2. Flowering is accelerated in prosystemin overexpressing tomato plants. Compared to (a) wild-type (WT) untransformed tomato plants, (b) plants overexpressing the prosystemin (ProSys-OE) precursor protein of the systemin peptide hormone had an accelerated onset of flowering. The images show ProSys-OE and WT plants recorded 30, and 32 days post transplantation into pots, respectively.

\subsection{Photosynthetic Efficiency Parameters}

In general, Fv / Fm, PI and total chlorophyll content are unrelated measurements of photosynthetic efficiency. The chlorophyll Fv/Fm fluorescence ratio is an indication of the physiological state of the plants regarding the fitness of the foliar photosynthetic systems. It tests the efficiency of photosystem II in a dark-adapted state [65,66]. As expected, the $\mathrm{Fv} / \mathrm{Fm}$ ratios tended to be higher and more reproducible when measured in the early morning (Figure 3a). Significant lowering of some Fv/Fm ratios was detected in the afternoon measurements, which were more variable. However, no differences in this parameter were observed between WT and ProSys-OE plants. The same pattern was 
observed when the $\mathrm{PI}_{\text {total }}$ parameter, a reliable indicator of plant vitality, was measured (Figure 3b).

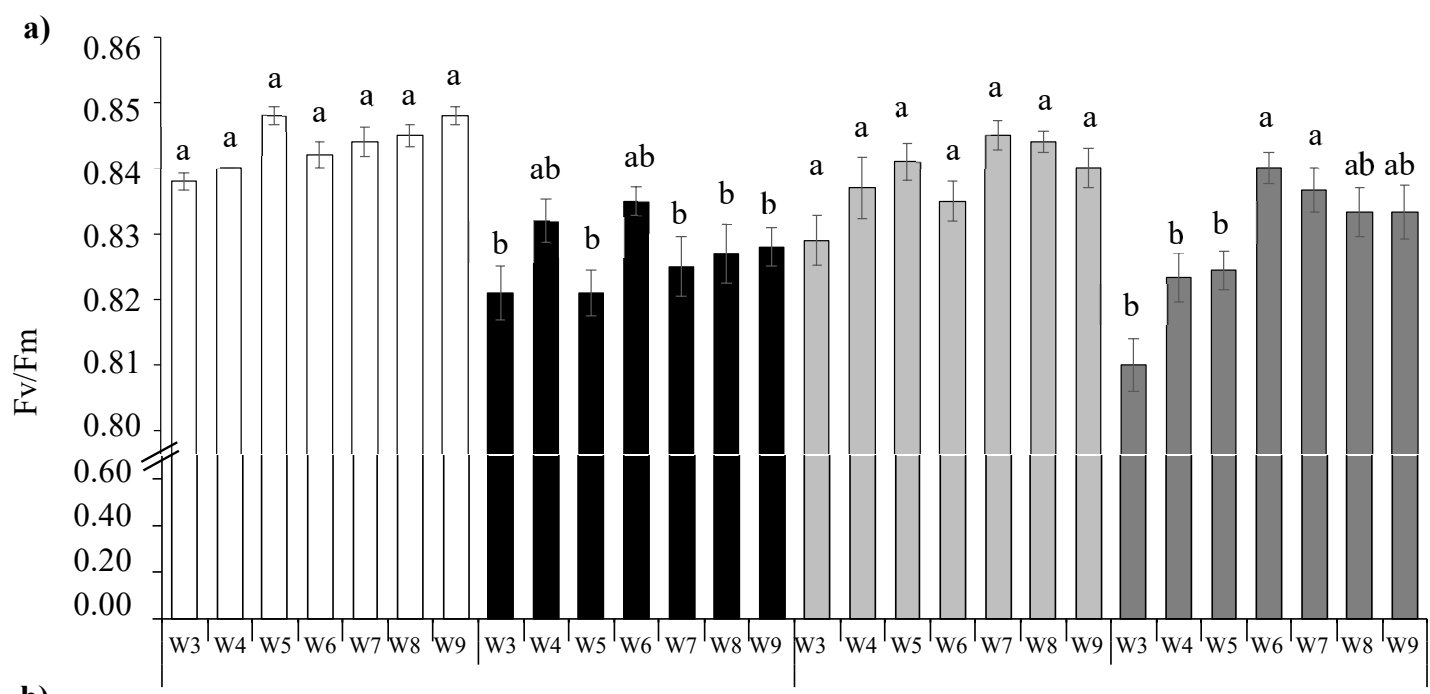

b)

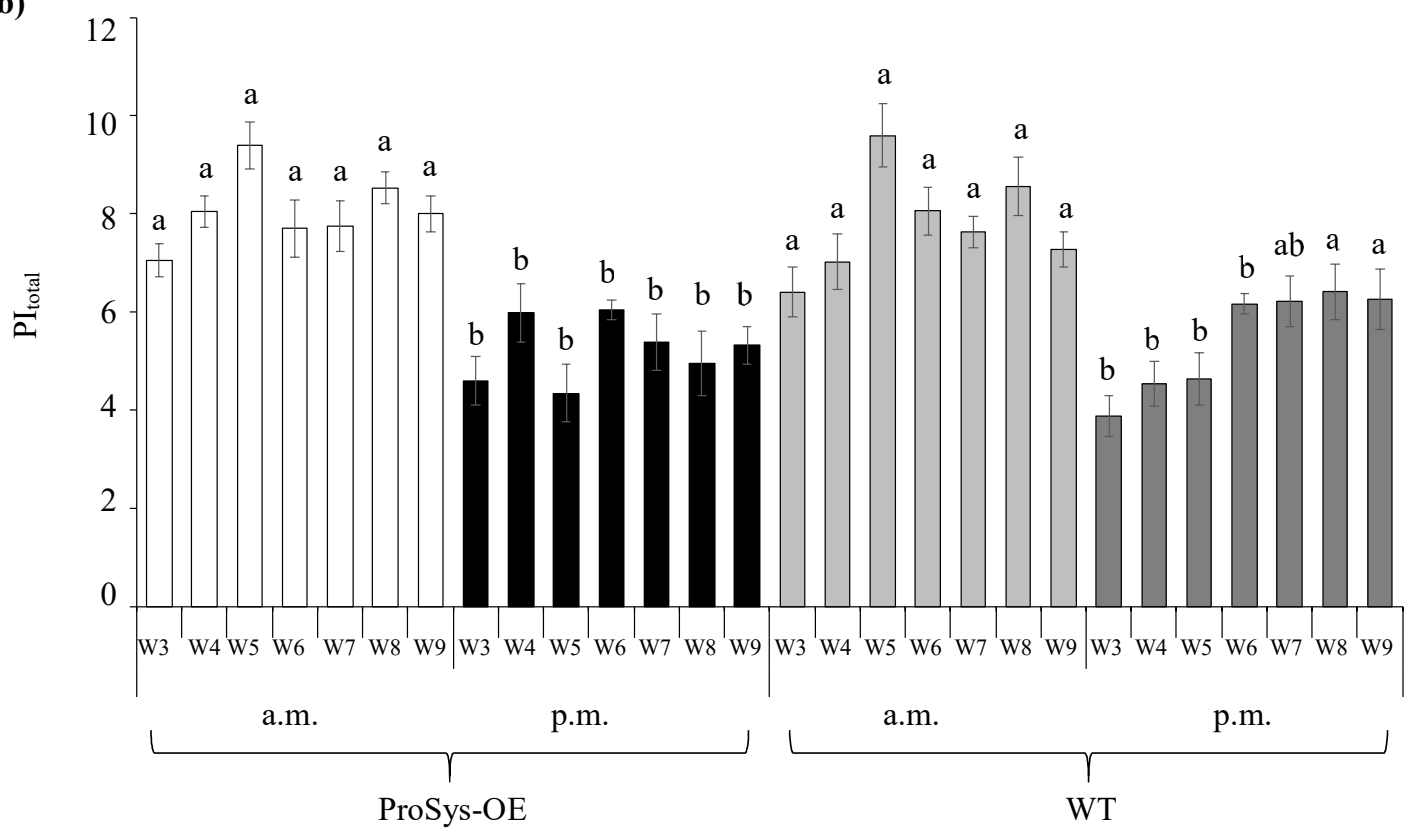

Figure 3. Photosynthetic performance of wild-type (WT) and prosystemin overexpressing (ProSys-OE) tomato plants. The measurement of (a) the photochemical efficiency of the PSII photosystem (determined as the Fv/Fm ratio), and (b) the plant photosynthetic performance, (as $\mathrm{PI}_{\text {total }}$ ), was measured in wild-type $(\mathrm{WT})$ untransformed tomato plants and in plants overexpressing the ProSys precursor protein of the systemin peptide hormone. WT and ProSys-OE tomato plants were monitored during a 7-week period (W3-W10) starting at week 3 (W3) after transplant. The bars represent the mean value of the measurements performed in 10 plants with three technical repetitions each. Different letters over the bars represent statistically significant differences at $p<0.05$ (Tukey test). The measurements were performed in the morning ( 8 a.m.) and afternoon (6 p.m.) in the spring-summer of 2019 in Irapuato, Gto. México.

This outcome was observed although $\mathrm{PI}_{\text {total }}$, an indicator of plant photosynthetic performance that quantifies the energy fluxes moving across the reaction centers and the photosystems via the JIP-test, is considered to be more sensitive to environmental disturbances $[67,68]$. Additionally, only punctual differences in the chlorophyll content in leaves, measured from the beginning of the flowering stage to the end of the fruiting phase, were detected in WT and ProSys-OE plants (Table 2). The fact that PI $\mathrm{I}_{\text {total }}$ and chlorophyll content remained practically unchanged during the course of the experiment in WT and 
ProSys-OE plants was indicative that both were maintained under non-stressful conditions. This was contrary to the notion that ProSys-OE plants may be under a constitutive woundrelated stress.

Table 2. Chlorophyll Content Index (CCI) in leaves of wild-type (WT) and prosystemin overexpressing (ProSys-OE) plants. CCI was determined in leaves of wild-type (WT) untransformed tomato plants and in plants overexpressing the ProSys precursor protein of the systemin peptide hormone. Measurements were made at 32, 39, 46, and 53 days post-transplantation (dpt) of seedlings into $5 \mathrm{~L}$ plant pots.

\begin{tabular}{ccccc}
\hline Genotype & $32 \mathbf{d p t}$ & $39 \mathbf{d p t}$ & $\mathbf{4 6 \mathbf { d p t }}$ & $\mathbf{5 3 \mathbf { d p t }}$ \\
\hline WT & $78.8 \pm 1.1 \mathrm{a}$ & $67.6 \pm 0.08 \mathrm{~b}$ & $73.2 \pm 11.3 \mathrm{a}$ & $68.8 \pm 1.0 \mathrm{a}$ \\
\hline ProSys-OE & $68.2 \pm 1.0 \mathrm{a}$ & $173.5 \pm 1.5 \mathrm{a}$ & $74.2 \pm 1.6 \mathrm{a}$ & $64.0 \pm 1.9 \mathrm{~b}$ \\
\hline
\end{tabular}

${ }^{1}$ Different letters represent statistically significant values (Tukey test, $p \leq 0.05$ ).

\subsection{Fruit Physicochemical Parameters}

Fresh tomato fruits are evaluated on the basis of several agronomic, organoleptic and nutritional qualities [69]. Larger tomato fruits were obtained from ProSys-OE plants starting from the second and third harvest, although the average fruit yield per plant was similar in both genotypes (Figure 4; Table 3). Attributes that were significantly higher in ProSys-OE fruits in at least one of the three harvests per plant performed were the following: weight, length and width, firmness, TSS and titratable acidity. Differences in seed number depended on the fruit size. While a significantly higher seed number was detected in very large ProSys-OE fruits, seed content in all other fruit sizes, except medium-sized fruits, was significantly higher in WT fruits. Color and luminosity attributes were no different in fruits obtained from WT and ProSys-OE plants (Table 3).

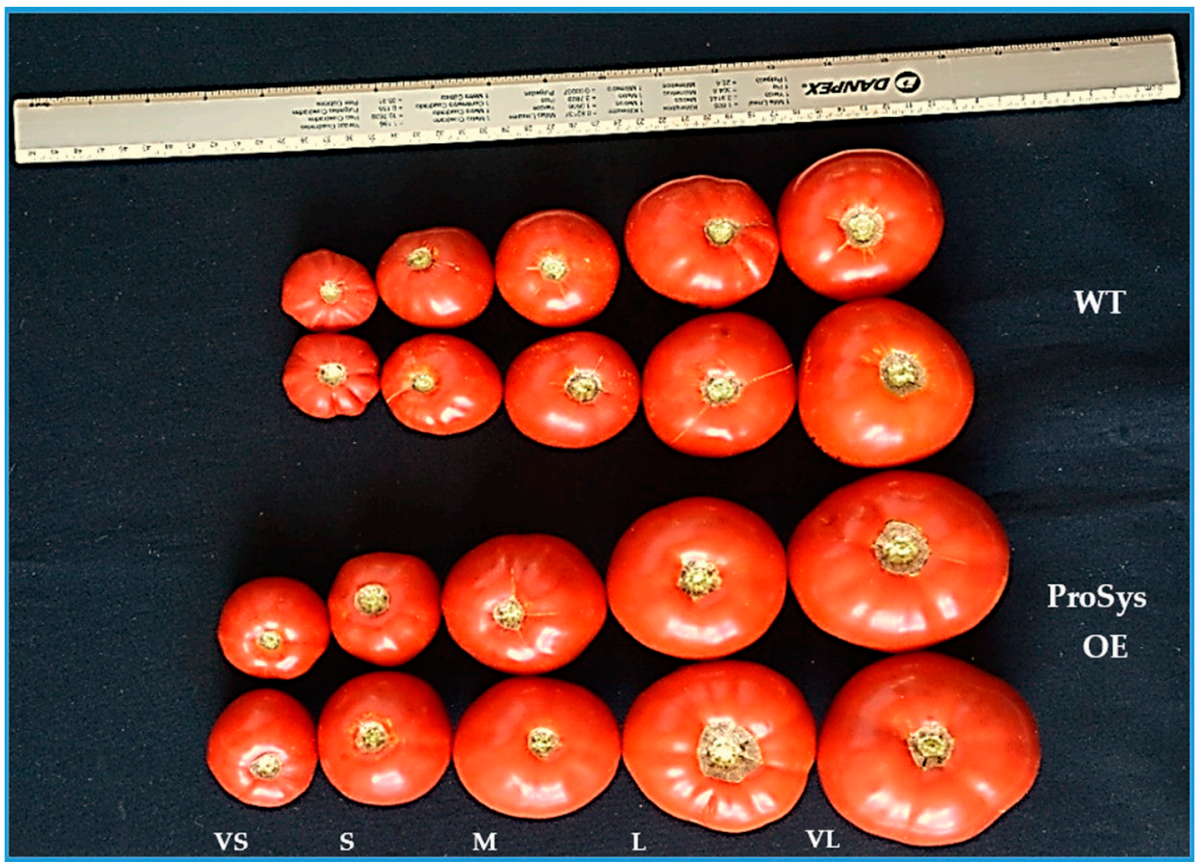

Figure 4. Increased size and weight of fruits produced by prosystemin overexpressing tomato plants. Compared to wild-type (WT) untransformed plants, the overexpression of the prosystemin (ProSys$\mathrm{OE}$ ) precursor protein of the systemin peptide hormone, led to the production of larger and heavier fruits. Shown in this image are five fruit sizes (very large (VL), large (L), medium (M), small (S) and very small (VS)) obtained from the second of a total of three harvest lots of WT and ProSys-OE tomato plants. 
Table 3. Physicochemical properties and reproductive traits of fruits harvested from wild-type (WT) and prosystemin overexpressing (ProSys-OE) plants. Fruits were obtained from WT untransformed tomato plants and from plants overexpressing the ProSys precursor protein of the systemin peptide hormone. Fruits from three different seasonal harvests and having different sizes were analyzed.

\begin{tabular}{|c|c|c|c|c|c|c|c|c|}
\hline & \multicolumn{8}{|c|}{ Genotype } \\
\hline \multirow[t]{2}{*}{$\begin{array}{l}\text { Harvest } \\
\mathbf{N}^{\circ}\end{array}$} & \multicolumn{3}{|c|}{ WT } & \multicolumn{5}{|c|}{ ProSys OE } \\
\hline & \multicolumn{8}{|c|}{ Fruit weight (g) } \\
\hline 1 & \multicolumn{3}{|c|}{$152.3 \pm 12.6 \mathrm{a}$} & \multicolumn{5}{|c|}{$177.4 \pm 18.0 \mathrm{a}$} \\
\hline 2 & \multicolumn{3}{|c|}{$94.7 \pm 8.1 \mathrm{~b}$} & \multicolumn{5}{|c|}{${ }^{1} 150.3 \pm 7.3 \mathrm{a}$} \\
\hline \multirow[t]{2}{*}{3} & \multicolumn{3}{|c|}{$125.9 \pm 7.6 \mathrm{~b}$} & \multicolumn{5}{|c|}{$145.9 \pm 5.5 \mathrm{a}$} \\
\hline & \multicolumn{8}{|c|}{ Fruit width $(\mathrm{cm})$} \\
\hline 1 & \multicolumn{3}{|c|}{$6.9 \pm 0.2 \mathrm{a}$} & \multicolumn{5}{|c|}{$7.1 \pm 0.3 \mathrm{a}$} \\
\hline 2 & \multicolumn{3}{|c|}{$5.9 \pm 0.2 \mathrm{~b}$} & \multicolumn{5}{|c|}{$6.9 \pm 0.2 \mathrm{a}$} \\
\hline \multirow[t]{2}{*}{3} & \multicolumn{3}{|c|}{$6.3 \pm 0.1 \mathrm{a}$} & \multicolumn{5}{|c|}{$6.6 \pm 0.1 \mathrm{a}$} \\
\hline & \multicolumn{8}{|c|}{ Fruit height $(\mathrm{cm})$} \\
\hline 1 & \multicolumn{3}{|c|}{$5.9 \pm 0.2 \mathrm{a}$} & \multicolumn{5}{|c|}{$6.4 \pm 0.3 \mathrm{a}$} \\
\hline 2 & & $5.0 \pm$ & & & & $5.9 \pm 0.1 \mathrm{a}$ & & \\
\hline 3 & & $5.4 \pm$ & & & & $5.8 \pm 0.1 \mathrm{a}$ & & \\
\hline & & & Numb & eeds/fruit size & & & & \\
\hline & & WT & & & & Sys OE & & \\
\hline & ${ }^{2} \mathrm{VL}$ & $\mathrm{M}$ & VS & $\mathrm{VL}$ & $\mathrm{L}$ & $\mathrm{M}$ & $\mathrm{s}$ & VS \\
\hline 3 & $174 \pm 65 \mathrm{a}$ & $\begin{array}{c}72 \pm 7 \\
\mathrm{a}\end{array}$ & $50 \pm 1 \mathrm{a}$ & $173 \pm 5 \mathrm{a}$ & $116 \pm 8 b$ & $\begin{array}{c}65 \pm 5 \\
a\end{array}$ & $37 \pm 8 b$ & $\begin{array}{c}19 \pm 1 \\
\mathrm{~b}\end{array}$ \\
\hline & & & Tota & ber of fruits & & & & \\
\hline $\begin{array}{c}1+2+ \\
3\end{array}$ & & $75 \pm 8$ & & & & $0 \pm 6$ & & \\
\hline & & & & olor & & & & \\
\hline & $\mathrm{L}$ & $\mathrm{C}$ & $\mathrm{H}$ & $\mathrm{L}$ & & C & & H \\
\hline 1 & $36.2 \pm 0.49 \mathrm{a}$ & $28.9 \pm 1.3 \mathrm{a}$ & $51.2 \pm 0.6 \mathrm{a}$ & $37.5 \pm 0.59 \mathrm{a}$ & & $30.7 \pm 1.0 \mathrm{a}$ & & $52.6 \pm 0.8 \mathrm{a}$ \\
\hline & & & & $\operatorname{ness}(\mathrm{N})$ & & & & \\
\hline 1 & & $0.29 \pm$ & & & & $0.37 \pm 0.2 \mathrm{a}$ & & \\
\hline & & & Titratable & $y$ (as \% citric acid) & & & & \\
\hline 2 & & $8.7 \pm 1$ & & & & $11.5 \pm 0.5 \mathrm{a}$ & & \\
\hline 3 & & $9.2 \pm 1$ & & & & $11.7 \pm 0.3 \mathrm{a}$ & & \\
\hline & & & Total Sol & olids (TSS; ${ }^{\circ}$ Brix) & & & & \\
\hline 1 & & $5.85 \pm$ & & & & $5.64 \pm 0.19 \mathrm{~b}$ & & \\
\hline 2 & & $5.12 \pm$ & & & & $5.27 \pm 0.03 \mathrm{a}$ & & \\
\hline 3 & & $5.21 \pm$ & & & & $5.24 \pm 0.06 \mathrm{a}$ & & \\
\hline & & & & $\mathrm{e}(\mathrm{mg} / \mathrm{g})$ & & & & \\
\hline 1 & & $113.9 \pm$ & & & & $129.2 \pm 5.78 \mathrm{a}$ & & \\
\hline 2 & & $93.7 \pm 1$ & & & & $103.1 \pm 2.63 \mathrm{a}$ & & \\
\hline & & & & e $(\mathrm{mg} / \mathrm{g})$ & & & & \\
\hline 1 & & $95.2 \pm 1$ & & & & $91.8 \pm 3.12 \mathrm{a}$ & & \\
\hline 2 & & $83.3 \pm 1$ & & & & $93.8 \pm 1.37 \mathrm{a}$ & & \\
\hline & & & & e $(\mathrm{mg} / \mathrm{g})$ & & & & \\
\hline 1 & & $7.16 \pm$ & & & & $9.9 \pm 0.64 \mathrm{a}$ & & \\
\hline 2 & & $5.45 \pm$ & & & & $6.7 \pm 0.32 \mathrm{a}$ & & \\
\hline & & & & $(\mathrm{mg} / \mathrm{g})$ & & & & \\
\hline 1 & & $1.26 \pm$ & & & & $1.7 \pm 0.32 \mathrm{a}$ & & \\
\hline 2 & & $0.63 \pm$ & & & & $0.96 \pm 0.10 \mathrm{a}$ & & \\
\hline
\end{tabular}

${ }^{1}$ Different letters represent statistically significant values (Tukey test, $p \leq 0.05$ ). ${ }^{2} \mathrm{VL}=$ very large; $\mathrm{L}=\mathrm{Large} ; \mathrm{M}=$ medium; $\mathrm{S}=$ small; VS = very small. 
NSC s content, determined in fruits produced in the first two harvests, was predominantly higher in ProSys-OE fruits. While only glucose and sucrose were significantly higher in ProSys-OE fruits obtained in the first harvest, all NSCs, including starch, were higher in ProSys-OE fruits obtained in the second harvest (Table 3).

Significant differences in other relevant metabolites associated with fruit quality were also detected in these fruits. Only seven metabolites were significantly different in fruits derived from the first harvest, most of which accumulated to significantly higher levels in WT fruits (Table 4). These included fumaric acid, DL-malic acid, oleic acid, maleic acid and L-glutamine. Only glyceric and 2-aminomalonic acid contents were significantly higher in ProSys-OE fruits. In this harvest, 2-propenoic acid was exclusively detected in WT fruits. The number of metabolites whose abundance became significantly different in WT and ProSys-OE fruits increased to 22 in the second harvest lot (Table 4). Those that accumulated to higher levels in ProSys-OE fruits were serine, phenylalanine, lactic acid and 2 -aminomalonic acid. Among the metabolites that were significantly more abundant in WT fruits harvested in the second lot were phosphoric and glyceric acids, amino acids (glycine, threonine, aspartic acid and L-5-oxo-1-proline), fatty acids (palmitic, stearic, oleic and linoleic acids), organic acids (acetic, malic, maleic, succinic and fumaric acids), glucuronic acid, D-xylose and myo-inositol.

\subsection{Quantitative Gene Expression Profiles}

The qPCR results shown in Table 5 confirmed that the ProSys gene was constitutively expressed in the ProSys-OE transgenic plants examined. Curiously, ProSys expression levels were much higher in roots than in leaves of ProSys-OE plants. The induction of early and late wound-response genes associated with JA signaling was in agreement with the "permanent wound response" phenotype that characterizes ProSys-OE plants [70]. The 9-LOX pathway was also positively impacted. The upregulated wound-response genes included early genes such as LHA1 and PLA2, coding for a member of the plasma membrane $\mathrm{H}^{+}$-ATPase gene family in tomato $[12,70]$ and for wound-inducible phospholipase believed to mediate the chloroplast membrane release of linolenic acid for JA synthesis, respectively [71,72]. LIPOXYGENASE D (LOXD) and ALLENE OXIDE SYNTHASE (AOS), two key octadecanoid pathway genes leading to JA biosynthesis [70], were also induced. The JASMONIC ACID CARBOXYL METHYLTRANSFERASE (JMT) and the JASMONATE ZIM DOMAIN2 (JAZ2) genes involved in downstream JA signaling were also activated in these plants. JAZ2 is one of several JAZ proteins capable of regulating the JA signaling pathway [73], whereas JMT catalyzes the synthesis of MeJA, an active JA volatile signal [74]. In addition, several late genes were induced in ProSys-OE plants, including PINII, PPOD, CYP2, SCP and AROGP3, coding for an emblematic protease inhibitor and other wound responsive enzymes such as polyphenol oxidase, cysteine protease, serine carboxypeptidase and a JA-regulated tomato polygalacturonase non-catalytic subunit gene $[70,75]$, respectively.

The 9-LOX and AOS3 genes, coding for enzymes that sequentially convert 9- hydroperoxide octadecadi(tri)enoic acids to 9,10-epoxy octadecadienoic acid and to either 10-oxo-phytodienoic acid or ketols, were strongly induced in ProSys-OE plants. The HPL gene, coding for an enzyme able to transform 9,10-epoxy octadecadienoic acid to 12-oxo-(Z)-9-dodecenoic acid, a precursor of the traumatin, and to (Z)-3-hexenal and other defense-related green-leaf volatiles, was also positively impacted in leaves of ProSys-OE tomato plants. The activation of the alternative 9-LOX pathway in ProSys-OE plants was in accordance with its role in the regulation of (a)biotic abiotic stress responses and plant development [76-78]. 
Table 4. Metabolites analysis of tomato fruits harvested from wild-type (WT) and prosystemin overexpressing (ProSys-OE) plants. The analysis was performed in fruits collected from WT untransformed plants and from plants overexpressing the ProSys precursor protein of the systemin peptide hormone. The metabolites listed correspond to those that were detected to accumulate to significantly different levels in fruits of either WT or ProSys-OE plants. They were identified by a targeted GC-MS analysis of fruits obtained from the first (1) and second (2) seasonal harvests.

\begin{tabular}{|c|c|c|}
\hline \multirow{3}{*}{ Compound/Genotype } & WT & ProSys-OE \\
\hline & \multicolumn{2}{|c|}{ Harvest 1} \\
\hline & Peak Area & Peak Area \\
\hline Glyceric acid & $4.67 \times 10^{5} \pm 88,316 \mathrm{~b}$ & $9.84 \times 10^{5} \pm 1.78 \times 10^{5} \mathrm{a}^{1}$ \\
\hline Aminomalonic acid & $2.5 \times 10^{5} \pm 58,383 \mathrm{~b}$ & $7.5 \times 10^{5} \pm 1.9 \times 10^{5} \mathrm{a}$ \\
\hline 2-E-butenedioic acid (fumaric acid) & $4.5 \times 10^{6} \pm 22,736 a$ & $2.33 \times 10^{6} \pm 41,209 \mathrm{~b}$ \\
\hline 2-Z-butenedioic acid (maleic acid) & $3.93 \times 10^{5} \pm 52,798 \mathrm{a}$ & $2.13 \times 10^{5} \pm 33,330 \mathrm{~b}$ \\
\hline DL-malic acid & $128.9 \times 10^{6} \pm 12.1 \times 10^{6} \mathrm{a}$ & $78.4 \times 10^{6} \pm 13.7 \times 10^{6} \mathrm{~b}$ \\
\hline Oleic acid & $1.06 \times 10^{6} \pm 198 \times 10^{5} \mathrm{a}$ & $5.16 \times 10^{5} \pm 85,215 \mathrm{~b}$ \\
\hline \multirow[t]{2}{*}{ L-glutamine } & $213.3 \times 10^{6} \pm 68.9 \times 10^{6} a$ & $45.3 \times 10^{6} \pm 7.1 \times 10^{6} \mathrm{~b}$ \\
\hline & \multicolumn{2}{|c|}{ Harvest 2} \\
\hline Acetic acid & $5.69 \times 10^{5} \pm 16,6626 \mathrm{a}$ & $1.01 \times 10^{5} \pm 18,607 \mathrm{~b}$ \\
\hline Phosphoric acid & $322.4 \times 10^{6} \pm 19.9 \times 10^{6} a$ & $157.9 \times 10^{6} \pm 22.7 \times 10^{6} \mathrm{~b}$ \\
\hline Glyceric acid & $1.21 \times 10^{6} \pm 1.07 \times 10^{5} \mathrm{a}$ & $6.47 \times 10^{5} \pm 90,612 b$ \\
\hline DL-malic acid & $86.1 \times 10^{6} \pm 5.7 \times 10^{6} a$ & $61.9 \times 10^{6} \pm 9.5 \times 10^{6} \mathrm{~b}$ \\
\hline Lactic acid & $1.6 \times 10^{5} \pm 73,308 \mathrm{~b}$ & $4.7 \times 10^{5} \pm 52,233 \mathrm{a}$ \\
\hline 2-E-butenedioic acid (fumaric acid) & $4.08 \times 10^{5} \pm 54,794 \mathrm{a}$ & $9.42 \times 10^{4} \pm 10,999 \mathrm{~b}$ \\
\hline 2-Z-butenedioic acid (maleic acid) & $4.18 \times 10^{5} \pm 89,174 \mathrm{a}$ & $1.14 \times 10^{5} \pm 15,125 b$ \\
\hline Butanedioic acid (succinic acid) & $5.9 \times 10^{6} \pm 7.06 \times 10^{5} \mathrm{a}$ & $2.43 \times 10^{6} \pm 1.8 \times 10^{5} \mathrm{~b}$ \\
\hline Aminomalonic acid & $3.19 \times 10^{5} \pm 43,011 \mathrm{~b}$ & $6.3 \times 10^{5} \pm 54,972 \mathrm{a}$ \\
\hline Hexadecanoic acid (palmitic acid) & $61.7 \times 10^{6} \pm 9.9 \times 10^{6} \mathrm{a}$ & $34.3 \times 10^{6} \pm 2.7 \times 10^{6} \mathrm{~b}$ \\
\hline Octadecanoic acid (stearic acid) & $32.2 \times 10^{6} \pm 4.01 \times 10^{6} \mathrm{a}$ & $16.9 \times 10^{6} \pm 1.52 \times 10^{6} \mathrm{~b}$ \\
\hline Oleic acid & $4.96 \times 10^{5} \pm 41,024 \mathrm{a}$ & $1.46 \times 10^{5} \pm 25,905 \mathrm{~b}$ \\
\hline Linoleic acid & $2.4 \times 10^{6} \pm 1.15 \times 10^{5} \mathrm{a}$ & $7.8 \times 10^{5} \pm 57,304 b$ \\
\hline Glycine & $53.5 \times 10^{4} \pm 10,788 \mathrm{a}$ & $23.2 \times 10^{4} \pm 3775 \mathrm{~b}$ \\
\hline L-threonine & $5.45 \times 10^{6} \pm 1.6 \times 10^{6} a$ & $1.17 \times 10^{6} \pm 2.84 \times 10^{5} \mathrm{~b}$ \\
\hline L-serine & $13.1 \times 10^{6} \pm 2.1 \times 10^{6} \mathrm{~b}$ & $34.7 \times 10^{6} \pm 4.1 \times 10^{6} \mathrm{a}$ \\
\hline L-phenylalanine & $3.9 \times 10^{6} \pm 8.6 \times 10^{5} \mathrm{~b}$ & $7.2 \times 10^{6} \pm 8.4 \times 10^{5} \mathrm{a}$ \\
\hline L-aspartic acid & $32.8 \times 10^{6} \pm 6.3 \times 10^{6} a$ & $8.9 \times 10^{6} \pm 1.4 \times 10^{6} \mathrm{~b}$ \\
\hline L-5-oxo-1-proline & $87.9 \times 10^{6} \pm 4.7 \times 10^{6} a$ & $70.3 \times 10^{7} \pm 3.8 \times 10^{6} \mathrm{~b}$ \\
\hline D-glucuronic acid & $11.9 \times 10^{6} \pm 1.7 \times 10^{6} a$ & $2.5 \times 10^{6} \pm 8.7 \times 10^{5} \mathrm{~b}$ \\
\hline Xylose & $9.05 \times 10^{6} \pm 6.9 \times 10^{5} \mathrm{a}$ & $4.05 \times 10^{6} \pm 2.7 \times 10^{5} \mathrm{~b}$ \\
\hline Myo-inositol & $1.34 \times 10^{6} \pm 1.03 \times 10^{5} \mathrm{a}$ & $8.84 \times 10^{5} \pm 76,541 b$ \\
\hline
\end{tabular}

${ }^{1}$ Different letters represent statistically significant values (Tukey test, $p \leq 0.05$ ). 
Table 5. Relative expression levels of wound-response and 9-LOX pathway genes in wild-type (WT) and prosystemin overexpressing (ProSys-OE) tomato plants. Genes were quantified in roots and leaves of WT untransformed plants and in plants overexpressing the ProSys precursor protein of the systemin peptide hormone.

\begin{tabular}{ccccccc}
\hline Gene/Gene Category & \multicolumn{3}{c}{ ROOTS } & \multicolumn{3}{c}{ LEAVES } \\
\hline Wound Response & WT & ProSys OE & P/W $\mathbf{~}^{2}$ & WT & ProSys OE & P/W \\
\hline PS & 10.006 & 155.7 & 25,950 & 3.8 & 128.5 & 33.8 \\
PLA 2 & 0.51 & 4.2 & 8.2 & ND $^{3}$ & ND & -4 \\
LHA & 4.6 & 7.1 & 1.5 & ND & ND & - \\
LOX D & 1.95 & 31.9 & 16.4 & 0.74 & 1.4 & 1.89 \\
AOS & 0.14 & 22.1 & 157.1 & ND & ND & - \\
JAZ 2 & 70.3 & 41.7 & 0.59 & ND & ND & - \\
JMT & 1.41 & 1.28 & 0.91 & 1.46 & 0.37 & 0.25 \\
PPOD & 2.1 & 6.3 & 3.0 & 0.013 & 0.24 & 18.5 \\
PIN II & 0.11 & 5.85 & 55.2 & 0.045 & 10.2 & 226.7 \\
CYP2 & 58.1 & 95.9 & 1.7 & ND & ND & - \\
SCP & 0.25 & 1.25 & 5.0 & 2.17 & 9.14 & 4.2 \\
AROGP3 & 0.6 & 3.4 & 5.7 & 0.17 & 0.45 & 2.6 \\
\hline 9-LOX & WT & ProSys OE & P/W & WT & ProSys OE & P/W \\
\hline LOX $A$ & 8.8 & 49.8 & 5.7 & ND & ND & - \\
HPL & 0.71 & 1.1 & 1.6 & 2.4 & 6.6 & 2.8 \\
AOS 3 & 2.7 & 37.2 & 13.8 & 0.0 & 0.0 & - \\
\hline
\end{tabular}

${ }^{1}$ Gene expression levels were calculated using the $2^{-\Delta \mathrm{Ct}}$ equation, according to Livak and Schmittgen [63].

${ }^{2}$ ProSys OE/WT gene expression ratio. ${ }^{3} \mathrm{ND}=$ not determined. ${ }^{4}$ The (-) symbol indicates that this gene was not analyzed.

\section{Discussion}

Prior to this study, and contrary to expectations, ProSys-OE plants were consistently observed to produce larger and more abundant fruits when cultivated for seed multiplication purposes. Fruits were also more attractive to herbivores that occasionally raided the green houses or fields where ProSys-OE plants were cultivated. Thus, this study was performed to confirm that ProSys-OE plants somehow eluded the fitness penalty that was previously shown to alter the growth, physiology and reproductive success of similarly transformed tomato plants [50]. Thus, negative vegetative growth rates and lower reproductive yields usually associated with the over-production of resource-demanding defense-related proteins, such as proteinase inhibitors, were not observed in ProSys-OE plants. Moreover, these plants yielded larger fruits with significantly different physicochemical properties.

The growth habit of ProSys-OE plants was different from WT plants. Although the transgenic plants were slow to develop, they quickly recovered and developed into taller plants, although with lower leaf number than WT plants. The onset of flowering was also earlier in these plants, whereas ProSys-OE fruits were also firmer, larger and heavier. However, the overall fruit yield per plant after three harvest lots was not different from WT plants, although the largest ProSys-OE fruits had significantly higher seed number than comparable WT fruits. The differential expression of genes coding for components of ET- and auxin-related signal transduction pathways, sugar metabolism enzymes and photosynthesis-related proteins in ProSys-OE plants [19] could partly explain these distinctive traits. They could have also contributed to the higher fruit firmness of ProSys-OE fruits, which was indicative of a slower fruit maturation rate [79,80]. The latter is a complex and not fully understood process. It may be argued that certain cultivation practices, such as $\mathrm{Ca}^{2+}$ complementation during vegetative growth, may have positively affected these fruit quality parameters. Thus, increased $\mathrm{Ca}^{2+}$ could have contributed to enhanced (pro)systemin-mediated responses thought to be controlled by $\mathrm{Ca}^{2+}$ and reactive oxygen species sensing mechanisms [19]. Additionally, exogenous calcium application may have 
helped to maintain the fruit's cell wall integrity, consequently increasing their resistance to cell wall-degrading enzymes [81].

All photosynthesis-efficiency-related results obtained in the present study indicated that ProSys-OE plants were as vigorous as WT plants. In addition, the significantly higher levels of NSCs detected in ProSys-OE fruits strongly suggested that ProSys-OE plants were not limited in their ability to provide carbon resources to strong sink tissues such as developing fruits. This was indicative that photosynthetic efficiency and C-allocation to sink tissues was not affected in the ProSys-OE plants analyzed in the present study. This outcome was evidence that the induction of defense responses in these plants did not negatively affect their photosynthetic efficiency. A similar conclusion was reached by a study in Arabidopsis that reported no significant reduction of the quantum efficiency of photosystem II despite of the fact that the induction of defense responses was accompanied by the repressed expression of photosynthesis genes [82].

Likewise, some of the positive effects observed in the ProSys-OE plants could be attributed to the close relationship that Sys and JA have in the regulation of the wound response via the Sys-induced local synthesis of JAs and consequent amplification of the JA-based systemic signal $[7,52,83]$. In this respect, altered JA levels could have contributed to the production of larger ProSys-OE fruits, most of which had fewer seeds than WT fruits, similar to the effect observed in tomato plants exogenously treated with a highdose of foliar JA [40]. Modified JA levels could also have been linked to a jasmonaterelated reconfiguration of central plant metabolism [48] leading to the increased content of serine and phenylalanine detected in ProSys-OE fruits. These effects could be explained evoking the known interaction of JA with various transcription factors (TFs) able to regulate either the expression of multiple plant and development-related genes [84], the cross-talk of JA with growth regulating phytohormones, predominantly auxins, brassinosteroids and gibberellins $[28,85]$, or both. This proposal is further supported by several reports describing the positive effects that pre-harvest treatments with exogenous JA or MeJA have on important fruit traits, such as either time to ripening, fruit size and yield and metabolite profiles in several plants, including tomatoes [86-93]. However, this mechanistic proposal can only be tentative considering that JA-phytohormone interactions usually repress growth in favor of defense responses [28,44,46-48,94]. Additionally, the induction of genes coding for JAZ repressor proteins of JA signaling [68,95] in ProSys-OE plants [19] (this study), could represent the activation of a feedback mechanism designed to restrain JA-related responses.

Another line of reasoning could be that the enhanced development and reproductive output observed in ProSys-OE plants was a JA-independent response promoted by ProSys itself. This possibility was first suggested by a study that hinted that the ProSys gene could play a dual role in defense and development [96]. It was later reinforced by transcriptomic data that implied that the systemin signaling pathway could regulate developmental processes in tomato via ET, auxins and brassinosteroids [19]. Finally, a recent study revealed that ProSys-OE plants had wild-type levels of JA, thereby annulling the notion that the characteristic wound-activated phenotype of these plants was due to a JA overaccumulation [97]. Their observation that ProSys overexpression had a strong impact on the metabolism of tomato supported the possibility that this precursor protein was responsible for the modified physicochemical profiles, e.g., an altered metabolite composition and a significantly higher firmness, monitored in the ProSys-OE fruits analyzed in the present study. Interestingly, the latter could have been a consequence of the positive effect that ProSys overexpression was found to have on lignan biosynthesis and, therefore, cell wall composition and reinforcement [97].

The pleiotropic effects produced by ProSys overexpression in tomato could be related to the structural features of the ProSys protein itself, which was demonstrated to be an IDP having no stable or ordered three-dimensional structure [5]. IDPs are abundant in eukaryotic proteomes and include a high percentage of signaling proteins and TFs that actively participate in cell signaling and transcriptional regulation by being able to recog- 
nize and bind to various partners after undergoing disorder-to-order transitions [98-102]. Thus, it might be hypothesized that ProSys participates, as an IDP, in the modulation of plant development signaling by integrating signals from multiple plant growth regulatory and ambient cues, similar to other plant IDP TFs involved in stress and light-regulated transcriptional activation $[103,104]$. It is relevant to emphasize that, within this group, the Long Hypocotyl 5 TF was recently reported to be an important player in the JA-regulated trade-off between growth and defense $[105,106]$. This TF has also been considered to play a key role in the enhancement of tomato fruit ripening and yield produced in response to farred radiation, via the activation of sugar metabolism and transport leading to augmented tomato fruit sink strength [107-109]. Finally, compelling evidence in favor of ProSys being not simply the precursor of Sys but an integrator of multiple stress-related pathways has been produced by a body of emerging information showing that: (i) the overexpression of a truncated ProSys protein lacking the Sys-encoding segment, in tobacco plants, altered their proteomic profiles and increased their resistance against insect herbivores and necrotrophic fungi [110], and (ii) the exogenous treatment of tomato plants with ProSys-related short peptides different from Sys were found to have biological activity as revealed by modified associations with plant growth promoting bacteria and mycorrhizal fungi [111-114]; Molisso et al., unpublished data; Délano-Frier et al., unpublished data.

Although the mechanisms underlying this dual function are not well understood, the strategic positioning of the Sys/ProSys regulatory process in the midst of the defense vs. development alternative has the potential to be utilized to improve agricultural practices and crop yields. This objective could be accomplished, via Sys/ProSys, by increasing the defensive capability of plants against biotic stressors or by enhancing the association with beneficial plant growth-promoting microorganisms, without the generation of negative trade-off effects on productivity and on the surrounding environment.

\section{Conclusions}

The results obtained in this study indicated that the constitutive activation of the Sys/ProSys signaling pathway favors growth and reproductive output in tomato plants. These positive effects were indicative that this signaling pathway has a multiple regulatory capacity that is able to control the defense-development balance in tomato plants. This key regulatory role could be achieved via the close relationship shared by Sys/ProSys with the AJ signaling pathways or by the flexibility conferred by prosystemin's behavior as an IDP, enabling it to integrate defense- and development-related responses. The resolution of these proposals has the potential to permit a better understanding of the mechanisms utilized by plants to efficiently allocate resources for growth and defense. The application that this knowledge could have for improved crop management and productivity are evident.

Supplementary Materials: The following are available online at https://www.mdpi.com/article/10 .3390 /agronomy11061148/s1, Table S1: Oligonucleotides employed for qPCR analysis of woundresponse and Lox-9 pathway genes in untransformed and prosystemin overexpressing tomato plants.

Author Contributions: Conceptualization, J.P.D.-F., M.C. and R.R.; methodology, M.L.-M., N.M.-G., S.M.M., J.P.D.-F., R.R.; validation, J.P.D.-F., M.C., R.R.; formal analysis, M.L.-M., N.M.-G., K.C.-C., J.P.D.-F.; investigation, M.L.-M., J.P.D.-F., M.C., S.M.M., R.R.; resources, S.M.M., R.R., J.P.D.-F.; data curation, N.M.-G., J.P.D.-F.; writing-original draft preparation, J.P.D.-F., R.R.; writing-review and editing, J.P.D.-F., R.R.; visualization, S.M.M., M.C., R.R., J.P.D.-F.; supervision, R.R., J.P.D.-F.; project administration, S.M.M., R.R., J.P.D.-F.; funding acquisition, R.R., J.P.D.-F. All authors have read and agreed to the published version of the manuscript.

Funding: This research received no external funding.

Institutional Review Board Statement: Not applicable.

Informed Consent Statement: Not applicable.

Data Availability Statement: Not applicable. 
Acknowledgments: We are grateful to Gregg Howe (Michigan State University) for kindly supplying the ProSys-OE tomato seeds and the Tomato Genetic Resource Center at the University of California, Davis, for donating the cv. Castlemart tomato seeds. This work was supported by AMEXID (Agencia Mexicana de Cooperación Internacional para el Desarrollo) as part of the 2018-2020 Italy-Mexico mobility project entitled: Peptides of plant origin and arbuscular mycorrhizal fungi as natural amplifiers of the resistance of agricultural crops to biotic stress (code MX18MO02).

Conflicts of Interest: The authors declare no conflict of interest.

\section{References}

1. Pearce, G.; Strydom, D.; Johnson, S.; Ryan, C.A. A polypeptide from tomato leaves induces wound-inducible proteinase inhibitor proteins. Science 1991, 253, 895-897. [CrossRef] [PubMed]

2. McGurl, B.; Pearce, G.; Orozco-Cardenas, M.; Ryan, C.A. Structure, expression, and antisense inhibition of the systemin precursor gene. Science 1992, 255, 1570-1573. [CrossRef] [PubMed]

3. McGurl, B.; Orozco-Cardenas, M.; Pearce, G.; Ryan, C.A. Overexpression of the prosystemin gene in transgenic tomato plants generates a systemic signal that constitutively induces proteinase inhibitor synthesis. Proc. Natl. Acad. Sci. USA 1994, 91, 9799-9802. [CrossRef] [PubMed]

4. $\quad$ Beloshistov, R.E.; Dreizler, K.; Galiullina, R.A.; Tuzhikov, A.I.; Serebryakova, M.V.; Reichardt, S.; Shaw, J.; Taliansky, M.E.; Pfannstiel, J.; Chichkova, N.V.; et al. Phytaspase-mediated precursor processing and maturation of the wound hormone systemin. New Phytol. 2018, 218, 1167-1178. [CrossRef] [PubMed]

5. Buonanno, M.; Coppola, M.; Di Lelio, I.; Molisso, D.; Leone, M.; Pennacchio, F.; Langella, E.; Rao, R.; Monti, S.M. Prosystemin, a prohormone that modulates plant defense barriers, is an intrinsically disordered protein. Protein Sci. 2018, 27, 620-632. [CrossRef]

6. Ryan, C.A.; Pearce, G. Systemins: A functionally defined family of peptide signals that regulate defensive genes in Solanaceae species. Proc. Natl. Acad. Sci. USA 2003, 100, 14577-14580. [CrossRef]

7. Ryan, C.A.; Moura, D.S. Systemic wound signaling in plants: A new perception. Proc. Natl. Acad. Sci. USA 2002, 99, 6519-6520. [CrossRef]

8. Howe, G.A.; Schaller, A. Direct defenses in plants and their induction by wounding and insect herbivores. In Induced Plant Resistance against Herbivory; Schaller, A., Ed.; Springer: Heidelberg, Germany, 2008; pp. 7-29.

9. Wang, L.; Einig, E.; Almeida-Trapp, M.; Albert, M.; Fliegmann, J.; Mithofer, A.; Kalbacher, H.; Felix, G. The systemin receptor SYR1 enhances resistance of tomato against herbivorous insects. Nat. Plants 2018, 4, 152-156. [CrossRef]

10. Felix, G.; Boller, T. Systemin induces rapid ion fluxes and ethylene biosynthesis in Lycopersicon peruvianum cells. Plant J. 1995, 7, 381-389. [CrossRef]

11. Moyen, C.; Hammond-Kosack, K.E.; Jones, J.; Knight, M.R.; Johannes, E. Systemin triggers an increase of cytoplasmic calcium in tomato mesophyll cells: $\mathrm{Ca}^{2+}$ mobilization from intra- and extracellular compartments. Plant Cell Environ. 1998, 21, 1101-1111. [CrossRef]

12. Schaller, A.; Oecking, C. Modulation of plasma membrane $\mathrm{H}^{+}$-ATPase activity differentially activates wound and pathogen defense responses in tomato plants. Plant Cell 1999, 11, 263-272.

13. Ahmad, F.H.; Wu, X.; Stintzi, A.; Schaller, A.; Schulze, W.X. The systemin signaling cascade as derived from time course analyses of the systemin-responsive phosphoproteome. Mol. Cell Proteom. 2019, 18, 1526-1542. [CrossRef]

14. Hou, S.; Liu, Z.; Shen, H.; Wu, D. Damage-associated molecular pattern-triggered immunity in plants. Front. Plant Sci. 2019, 10, 646. [CrossRef]

15. Narváez-Vásquez, J.; Ryan, C.A. The cellular localization of prosystemin: A functional role for phloem parenchyma in systemic wound signaling. Planta 2004, 218, 360-369.

16. Orozco-Cardenas, M.; McGurl, B.; Ryan, C.A. Expression of an antisense prosystemin gene in tomato plants reduces resistance toward Manduca sexta larvae. Proc. Natl. Acad. Sci. USA 1993, 90, 8273-8276. [CrossRef]

17. Diaz, J.; ten Have, A.; van Kan, J.A. The role of ethylene and wound signaling in resistance of tomato to Botrytis cinerea. Plant Physiol. 2002, 129, 1341-1351. [CrossRef]

18. El Oirdi, M.; El Rahman, T.A.; Rigano, L.; El Hadrami, A.; Rodriguez, M.C.; Daayf, F.; Vojnov, A.; Bouarab, K. Botrytis cinerea manipulates the antagonistic effects between immune pathways to promote disease development in tomato. Plant Cell 2011, 23, 2405-2421. [CrossRef]

19. Coppola, M.; Corrado, G.; Coppola, V.; Cascone, P.; Martinelli, R.; Digilio, M.C.; Pennacchio, F.; Rao, R. Prosystemin overexpression in tomato enhances resistance to different biotic stresses by activating genes of multiple signaling pathways. Plant Mol. Biol. Rep. 2015, 33, 1270-1285. [CrossRef]

20. Bubici, G.; Carluccio, A.V.; Stavolone, L.; Cillo, F. Prosystemin overexpression induces transcriptional modifications of defenserelated and receptor-like kinase genes and reduces the susceptibility to Cucumber mosaic virus and its satellite RNAs in transgenic tomato plants. PLoS ONE 2017, 12, e0171902. [CrossRef]

21. Corrado, G.; Sasso, R.; Pasquariello, M.; Iodice, L.; Carretta, A.; Cascone, P.; Ariati, L.; Digilio, M.; Guerrieri, E.; Rao, R. Systemin regulates both systemic and volatile signaling in tomato plants. J. Chem. Ecol. 2007, 33, 669-681. [CrossRef] 
22. Coppola, M.; Cascone, P.; Madonna, V.; Di Lelio, I.; Esposito, F.; Avitabile, C.; Romanelli, A.; Guerrieri, E.; Vitiello, A.; Pennacchio, F.; et al. Plant-to-plant communication triggered by systemin primes anti-herbivore resistance in tomato. Sci. Rep. 2017, 7, 15522. [CrossRef] [PubMed]

23. Dombrowski, J.E. Salt stress activation of wound-related genes in tomato plants. Plant Physiol. 2003, 132, 2098-2107. [CrossRef]

24. Orsini, F.; Cascone, P.; De Pascale, S.; Barbieri, G.; Corrado, G.; Rao, R.; Maggio, A. Systemin-dependent salinity tolerance in tomato: Evidence of specific convergence of abiotic and biotic stress responses. Physiol. Plant. 2010, 138, 10-21. [CrossRef]

25. Coppola, M.; Di Lelio, I.; Romanelli, A.; Gualtieri, L.; Molisso, D.; Ruocco, M.; Avitabile, C.; Natale, R.; Cascone, P.; Guerrieri, E.; et al. Tomato plants treated with systemin peptide show enhanced levels of direct and indirect defense associated with increased expression of defense-related genes. Plants 2019, 8, 395. [CrossRef]

26. Valverde, P.L.; Fornoni, J.; Nunez-Farfan, J. Evolutionary ecology of Datura stramonium: Equal plant fitness benefits of growth and resistance against herbivory. J. Evol. Biol. 2003, 16, 127-137. [CrossRef] [PubMed]

27. Heidel, A.J.; Clarke, J.D.; Antonovics, J.; Dong, X.N. Fitness costs of mutations affecting the systemic acquired resistance pathway in Arabidopsis thaliana. Genetics 2004, 168, 2197-2206. [CrossRef]

28. Huot, B.; Yao, J.; Montgomery, B.L.; He, S.Y. Growth-defense tradeoffs in plants: A balancing act to optimize fitness. Mol. Plant 2014, 7, 1267-1287. [CrossRef]

29. Machado, R.A.R.; Baldwin, I.T.; Erb, M. Herbivory-induced jasmonates constrain plant sugar accumulation and growth by antagonizing gibberellin signaling and not by promoting secondary metabolite production. New Phytol. 2017, 215, 803-812 [CrossRef] [PubMed]

30. Simms, E.L.; Rausher, M.D. Costs and benefits of plant resistance to herbivory. Am. Nat. 1987, 130, 570-581. [CrossRef]

31. Herms, D.A.; Mattson, W.J. The dilemma of plants: To grow or defend. Q. Rev. Biol. 1992, 67, 283-335. [CrossRef]

32. Heil, M.; Baldwin, I.T. Fitness costs of induced resistance: Emerging experimental support for a slippery concept. Trends Plant Sci. 2002, 7, 61-67. [CrossRef]

33. Vos, I.A.; Pieterse, C.M.J.; Van Wees, S.C.M. Costs and benefits of hormone-regulated plant defences. Plant Pathol. 2013, 62, 43-55. [CrossRef]

34. Cipollini, D.; Walters, D.; Voelckel, C. Costs of resistance in plants: From theory to evidence. In Annual Plant Reviews: Insect-Plant Interactions; Voelckel, C., Jander, G., Eds.; John Wiley \& Sons: Hoboken, NJ, USA, 2014; pp. 263-307.

35. Karasov, T.L.; Chae, E.; Herman, J.J.; Bergelson, J. Mechanisms to mitigate the trade-off between growth and defense. Plant Cell 2017, 29, 666-680. [CrossRef]

36. Züst, T.; Agrawal, A.A. Trade-offs between plant growth and defense against insect herbivory: An emerging mechanistic synthesis. Annu. Rev. Plant Biol. 2017, 68, 513-534. [CrossRef]

37. Bowling, S.A.; Guo, A.; Cao, H.; Gordon, A.S.; Klessig, D.F.; Dong, X. A mutation in Arabidopsis that leads to constitutive expression of systemic acquired resistance. Plant Cell 1994, 6, 1845-1857.

38. Heil, M.; Hilpert, A.; Kaiser, W.; Linsenmair, K.E. Reduced growth and seed set following chemical induction of pathogen defence: Does systemic acquired resistance (SAR) incur allocation costs? J. Ecol. 2000, 88, 645-654. [CrossRef]

39. Li, X.; Clarke, J.D.; Zhang, Y.; Dong, X. Activation of an EDS1-mediated R-gene pathway in the snc1 mutant leads to constitutive, NPR1- independent pathogen resistance. Mol. Plant Microbe Interact. 2001, 14, 1131-1139. [CrossRef]

40. Redman, A.M.; Cipollini, D.F.; Schultz, J.C. Fitness costs of jasmonic acid-induced defense in tomato, Lycopersicon esculentum. Oecologia 2001, 126, 380-385. [CrossRef]

41. Zavala, J.A.; Patankar, A.G.; Gase, K.; Baldwin, I.T. Constitutive and inducible trypsin proteinase inhibitor production incurs large fitness costs in Nicotiana attenuata. Proc. Natl. Acad. Sci. USA 2004, 101, 1607-1612. [CrossRef]

42. Ballaré, C.L. Light regulation of plant defense. Annu. Rev. Plant Biol. 2014, 65, 335-363. [CrossRef]

43. Havko, N.E.; Major, I.T.; Jewell, J.B.; Attaran, E.; Browse, J.; Howe, G.A. Control of carbon assimilation and partitioning by jasmonate: An accounting of growth-defense tradeoffs. Plants 2016, 5, 7. [CrossRef]

44. Campos, M.L.; Yoshida, Y.; Major, I.T.; de Oliveira Ferreira, D.; Weraduwage, S.M.; Froehlich, J.E.; Johnson, B.F.; Kramer, D.M.; Jander, G.; Sharkey, T.D.; et al. Rewiring of jasmonate and phytochrome B signalling uncouples plant growth-defense tradeoffs. Nat. Commun. 2016, 7, 12570. [CrossRef]

45. Kliebenstein, D.J. False idolatry of the mythical growth versus immunity trade-off in molecular systems plant pathology. Physiol. Mol. Plant Pathol. 2016, 95, 55-59. [CrossRef]

46. Guo, Q.; Major, I.T.; Howe, G.A. Resolution of growth-defense conflict: Mechanistic insights from jasmonate signaling. Curr. Opin. Plant Biol. 2018, 44, 72-81. [CrossRef]

47. Ballaré, C.L.; Austin, A.T. Recalculating growth and defense strategies under competition: Key roles of photoreceptors and jasmonates. J. Exp. Bot. 2019, 70, 3425-3434. [CrossRef] [PubMed]

48. Savchenko, T.V.; Rolletschek, H.; Dehesh, K. Jasmonates-mediated rewiring of central metabolism regulates adaptive responses. Plant Cell Physiol. 2019, 60, 2613-2620. [CrossRef] [PubMed]

49. Fernández-Milmanda, G.L.; Crocco, C.D.; Reichelt, M.; Mazza, C.A.; Köllner, T.G.; Zhang, T.; Cargnel, M.D.; Lichy, M.Z.; Fiorucci, A.S.; Fankhauser, C.; et al. A light-dependent molecular link between competition cues and defence responses in plants. Nat. Plants 2020, 6, 223-230. [CrossRef]

50. Corrado, G.; Agrelli, D.; Rocco, M.; Basile, B.; Marra, M.; Rao, R. Systemin-inducible defence against pests is costly in tomato. Biol. Plant. 2011, 55, 305-311. [CrossRef] 
51. Ryan, C.A.; Pearce, G. Systemin: A polypeptide signal for plant defensive genes. Annu. Rev. Cell Dev. Biol. 1998, $14,1-17$. [CrossRef]

52. Schilmiller, A.L.; Howe, G.A. Systemic signaling in the wound response. Curr. Opin. Plant Biol. 2005, 8, 369-377. [CrossRef]

53. Metodiev, M.V.; Tsonev, T.D.; Popova, L.P. Effect of jasmonic acid on the stomatal and non-stomatal limitation of leaf photosynthesis in barley leaves. J. Plant Growth Regul. 1996, 15, 75-80. [CrossRef]

54. Herde, O.; Pena-Cortes, H.; Willmitzer, L.; Fisahn, J. Stomatal responses to jasmonic acid, linolenic acid and abscisic acid in wild-type and ABA-deficient tomato plants. Plant Cell Environ. 1997, 20, 136-141. [CrossRef]

55. Biber, P.D. Evaluating a chlorophyll content meter on three coastal wetland plant species. J. Agric. Food Environ. Sci. 2007, 24, 1-15.

56. CIE. CIE 15: Technical Report Colorimetry, 3rd ed.; International Commission on Illumination (CIE): Vienna, Austria, 2004; ISBN 3901906339.

57. 942.15. Acidity (Titratable) of Fruit Products. First Action 1942; AOAC, Association of Official Analytical Chemists: Washington, DC, USA, 1990.

58. Wright, D.P.; Scholes, J.D.; Read, D.J. Effects of VA mycorrhizal colonization on photosynthesis and biomass production of Trifolium repens L. Plant Cell Environ. 1998, 21, 209-216. [CrossRef]

59. Tiessen, A.; Hendriks, J.H.M.; Stitt, M.; Branscheid, A.; Gibon, Y.; Farré, E.M.; Geigenberger, P. Starch synthesis in potato tubers is regulated by post-translational redox modification of ADP-glucose pyrophosphorylase: A novel regulatory mechanism linking starch synthesis to the sucrose supply. Plant Cell 2002, 14, 2191-2213. [CrossRef]

60. Ramírez-Briones, E.; Rodríguez-Macías, R.; Salcedo-Pérez, E.; Ramírez-Chávez, E.; Molina-Torres, J.; Tiessen, A.; Ordaz-Ortiz, J.; Martínez-Gallardo, N.; Délano-Frier, J.P.; Zañudo-Hernández, J. Seasonal changes in the metabolic profiles and biological activity in leaves of Diospyros digyna and D. rekoi "Zapote" trees. Plants 2019, 8, 449. [CrossRef]

61. Casarrubias-Castillo, K.; Montero-Vargas, J.M.; Dabdoub-González, N.; Winkler, R.; Martinez-Gallardo, N.A.; Zañudo-Hernández, J.; Avilés-Arnaut, H.; Délano-Frier, J.P. Distinct gene expression and secondary metabolite profiles in suppressor of prosysteminmediated responses2 (spr2) tomato mutants having impaired mycorrhizal colonization. PeerJ 2020, 8, e8888. [CrossRef]

62. Mueller, L.A.; Solow, T.H.; Taylor, N.; Skwarecki, B.; Buels, R.; Binns, J.; Lin, C.; Wright, M.H.; Ahrens, R.; Wang, Y.; et al. The SOL genomics network: A comparative resource for Solanaceae biology and beyond. Plant Physiol. 2005, 138, 1310-1317. [CrossRef]

63. Livak, K.J.; Schmittgen, T.D. Analysis of relative gene expression data using real-time quantitative PCR and the $2^{-\Delta \Delta C t}$ method. Methods 2001, 25, 402-408. [CrossRef]

64. Expósito-Rodríguez, M.; Borges, A.A.; Borges-Pérez, A.; Pérez, J.A. Selection of internal control genes for quantitative real-time RT-PCR studies during tomato development process. BMC Plant Biol. 2008, 8, 131. [CrossRef]

65. Baker, N.R.; Rosenqvist, E. Applications of chlorophyll fluorescence can improve crop production strategies: An examination of future possibilities. J. Exp. Bot. 2004, 55, 1607-1621. [CrossRef]

66. Çiçek, N.; Arslan, O.; Çulha-Erdal, S.; Eyidoğan, F.; Ekmekçi, Y. Are the photosynthetic performance indexes and the drought factor index satisfactory selection criterion for stress? Fresenius Environ. Bull. 2015, 24, 4190-4198.

67. Strasser, R.J.; Srivastava, A.; Tsimilli-Michael, M. The fluorescence transient as a tool to characterize and screen photosynthetic samples. In Probing Photosynthesis: Mechanism, Regulation and Adaptation; Yunus, M., Pathre, U., Mohanty, P., Eds.; Taylor and Francis: London, UK, 2000; pp. 443-480.

68. Tsimilli-Michael, M.; Strasser, R.J. In vivo assessment of stress impact on plants' vitality: Applications in detecting and evaluating the beneficial role of mycorrhization on host plants. In Mycorrhiza: State of the Art, Genetics and Molecular Biology, Eco-Function, Biotechnology, Eco-Physiology, Structure and Systematics; Varma, A., Ed.; Springer: Berlin, Germany, 2008; pp. $679-703$.

69. Aoun, A.B.; Lechiheb, B.; Benyahya, L.; Ferchichi, A. Evaluation of fruit quality traits of traditional varieties of tomato (Solanum lycopersicum) grown in Tunisia. Afr. J. Food Sci. 2013, 7, 350-354. [CrossRef]

70. Ryan, C.A. The systemin signaling pathway: Differential activation of plant defensive genes. Biochim. Biophys. Acta 2000, 1477, 112-121. [CrossRef]

71. Farmer, E.E.; Ryan, C.A. Octadecanoid precursors of jasmonic acid activate the synthesis of wound-inducible protease inhibitors. Plant Cell 1992, 4, 129-134. [CrossRef]

72. Narváez-Vásquez, J.; Florin-Christensen, J.; Ryan, C.A. Positional specificity of a phospholipase A activity induced by wounding, systemin, and oligosaccharide elicitors in tomato leaves. Plant Cell 1999, 11, 2249-2260. [CrossRef]

73. Chung, H.S.; Niu, Y.; Browse, J.; Howe, G.A. Top hits in contemporary JAZ: An update on jasmonate signaling. Phytochemistry 2009, 70, 1547-1559. [CrossRef] [PubMed]

74. Seo, H.; Song, J.; Cheong, J.J.; Lee, Y.H.; Lee, Y.W.; Hwang, I.; Lee, J.S.; Choi, Y.D. Jasmonic acid carboxyl methyltransferase: A key enzyme for jasmonate-regulated plant responses. Proc. Natl. Acad. Sci. USA 2001, 98, 4788-4793. [CrossRef] [PubMed]

75. Bergey, D.R.; Orozco-Cardenas, M.; de Moura, D.S.; Ryan, C.A. A wound- and systemin-inducible polygalacturonase in tomato leaves. Proc. Natl. Acad. Sci. USA 1999, 96, 1756-1760. [CrossRef]

76. Vellosillo, T.; Martínez, M.; López, M.A.; Vicente, J.; Cascón, T.; Dolan, L.; Hamberg, M.; Castresana, C. Oxylipins produced by the 9-lip- oxygenase pathway in Arabidopsis regulate lateral root development and defense responses through a specific signaling cascade. Plant Cell 2007, 19, 831-846. [CrossRef]

77. Vicente, J.; Cascón, T.; Vicedo, B.; García-Agustín, P.; Hamberg, M.; Castresana, C. Role of 9-lipoxygenase and $\alpha$-dioxygenase oxylipin pathways as modulators of local and systemic defense. Mol. Plant 2012, 5, 914-928. [CrossRef] 
78. Upadhyay, R.K.; Handa, A.K.; Mattoo, A.K. Transcript abundance patterns of 9- and 13-lipoxygenase subfamily gene members in response to abiotic stresses (heat, cold, drought or salt) in tomato (Solanum lycopersicum L.) highlights member-specific dynamics relevant to each stress. Genes 2019, 10, 683. [CrossRef]

79. Schouten, R.E.; Huijben, T.P.M.; Tijskens, L.M.M.; van Kooten, O. Modelling quality attributes of truss tomatoes: Linking colour and firmness maturity. Postharvest Biol. Technol. 2007, 45, 298-306. [CrossRef]

80. Li, L.; Zhao, W.; Feng, X.; Chen, L.; Zhang, L.; Zhao, L. Changes in fruit firmness, cell wall composition, and transcriptional profile in the yellow fruit tomato 1 (yft1) mutant. J. Agric. Food Chem. 2019, 67, 463-472. [CrossRef]

81. White, P.J.; Broadley, M.R. Calcium in plants. Ann. Bot. 2003, 92, 487-511. [CrossRef]

82. Attaran, E.; Major, I.T.; Cruz, J.A.; Rosa, B.A.; Koo, A.J.; Chen, J.; Kramer, D.M.; He, S.Y.; Howe, G.A. Temporal dynamics of growth and photosynthesis suppression in response to jasmonate signaling. Plant Physiol. 2014, 165, 1302-1314. [CrossRef]

83. Katsir, L.; Chung, H.S.; Koo, A.J.K.; Howe, G.A. Jasmonate signaling: A conserved mechanism of hormone sensing. Curr. Opin. Plant Biol. 2008, 11, 428-435. [CrossRef]

84. Ruan, J.; Zhou, Y.; Zhou, M.; Yan, J.; Khurshid, M.; Weng, W.; Cheng, J.; Zhang, K. Jasmonic acid signaling pathway in plants. Int. J. Mol. Sci. 2019, 20, 2479. [CrossRef]

85. Yang, J.; Duan, G.; Li, C.; Liu, L.; Han, G.; Zhang, Y.; Wang, C. The crosstalks between jasmonic acid and other plant hormone signaling highlight the involvement of jasmonic acid as a core component in plant response to biotic and abiotic stresses. Front. Plant Sci. 2019, 10, 1349. [CrossRef]

86. Saniewski, M.; Czapski, J. The effect of methyl jasmonate on lycopene and $\beta$-carotene accumulation in ripening red tomatoes. Experientia 1983, 39, 1373-1374. [CrossRef]

87. Saniewski, M.; Nowacki, J.; Czapski, J. The effect of methyl jasmonate on ethylene production and ethylene-forming enzyme activity in tomatoes. J. Plant Physiol. 1987, 129, 175-180. [CrossRef]

88. Czapski, J.; Saniewski, M. Stimulation of ethylene production and ethylene-forming enzyme activity in fruits of the non-ripening nor and rin tomato mutants by methyl jasmonate. J. Plant Physiol. 1992, 139, 265-268. [CrossRef]

89. Yilmaz, H.; Yildiz, K.; Muradoğlu, F. Effect of jasmonic acid on yield and quality of two strawberry cultivars. J. Am. Pomol. Soc. 2003, 57, 32-35.

90. Concha, C.M.; Figueroa, N.E.; Poblete, L.A.; Oñate, F.A.; Schwab, W.; Figueroa, C.R. Methyl jasmonate treatment induces changes in fruit ripening by modifying the expression of several ripening genes in Fragaria chiloensis fruit. Plant Physiol. Biochem. 2013, 70, 433-444. [CrossRef] [PubMed]

91. Serrano, M.; Martínez-Esplá, A.; Zapata, P.; Castillo, S.; Martínez-Romero, D.; Guillén, F.; Valverde, J.M.; Valero, D. Effects of methyl jasmonate treatment on fruit quality properties. In Emerging Postharvest Treatment of Fruits and Vegetables; Barman, K., Sharma, S., Siddiqui, M.W., Eds.; Apple Academic Press: Palm Bay, FL, USA, 2018; pp. 85-106.

92. Hanaka, A.; Nurzyńska-Wierdak, R. Methyl jasmonate-A multifunctional molecule throughout the whole plant life. Acta Sci. Pol. Hortorum Cultus 2019, 18, 237-249. [CrossRef]

93. Zuñiga, P.E.; Castañeda, Y.; Arrey-Salas, O.; Fuentes, L.; Aburto, F.; Figueroa, C.R. Methyl jasmonate applications from flowering to ripe fruit stages of strawberry (Fragaria $\times$ ananassa 'Camarosa') reinforce the fruit antioxidant response at post-harvest. Front. Plant Sci. 2020, 11, 538. [CrossRef] [PubMed]

94. Major, I.T.; Guo, Q.; Zhai, J.; Kapali, G.; Kramer, D.M.; Howe, G.A. A phytochrome B-independent pathway restricts growth at high levels of jasmonate defense. Plant Physiol. 2020, 183, 733-749. [CrossRef]

95. Chung, H.S.; Koo, A.J.; Gao, X.; Jayanty, S.; Thines, B.; Jones, A.D.; Howe, G.A. Regulation and function of Arabidopsis JASMONATE ZIM domain genes in response to wounding and herbivory. Plant Physiol. 2008, 146, 952-964. [CrossRef]

96. Narváez-Vásquez, J.; Ryan, C.A. The systemin precursor gene regulates both defensive and developmental genes in Solanum tuberosum. Proc. Natl. Acad. Sci. USA 2002, 99, 15818-15821. [CrossRef]

97. Pastor, V.; Sanchez-Bel, P.; Gamir, J.; Pozo, M.J.; Flors, V. Accurate and easy method for systemin quantification and examining metabolic changes under different endogenous levels. Plant Methods 2018, 14, 33. [CrossRef] [PubMed]

98. Tompa, P. Intrinsically unstructured proteins. Trends Biochem. Sci. 2002, 27, 527-533. [CrossRef]

99. Oldfield, C.J.; Meng, J.; Yang, J.Y.; Yang, M.Q.; Uversky, V.N.; Dunker, A.K. Flexible nets: Disorder and induced fit in the associations of p53 and 14-3-3 with their partners. BMC Genom. 2008, 9, 1-20. [CrossRef] [PubMed]

100. Howton, T.C.; Zhan, Y.A.; Sun, Y.; Mukhtar, M.S. Intrinsically disordered proteins: Controlled chaos or random walk. Int. J. Plant Biol. 2015, 6, 6191. [CrossRef]

101. Niklas, K.J.; Dunker, A.K.; Yruela, I. The evolutionary origins of cell type diversification and the role of intrinsically disordered proteins. J. Exp. Bot. 2018, 69, 1437-1446. [CrossRef]

102. Wallmann, A.; Kesten, C. Common functions of disordered proteins across evolutionary distant organisms. Int. J. Mol. Sci. 2020, 21, 2105. [CrossRef] [PubMed]

103. Sun, X.; Jones, W.T.; Rikkerink, E.H.A. GRAS proteins: The versatile roles of intrinsically disordered proteins in plant signaling. Biochem. J. 2012, 442, 1-12. [CrossRef]

104. Sun, X.; Malhis, N.; Zhao, B.; Xue, B.; Gsponer, J.; Rikkerink, E.H.A. Computational disorder analysis in Ethylene Response Factors uncovers binding motifs critical to their diverse functions. Int. J. Mol. Sci. 2020, 21, 74. [CrossRef]

105. Gupta, N.; Prasad, V.B.R.; Chattopadhyay, S. LeMYC2 acts as a negative regulator of blue light mediated photomorphogenic growth, and promotes the growth of adult tomato plants. BMC Plant Biol. 2014, 14, 38. [CrossRef] 
106. Ortigosa, A.; Fonseca, S.; Franco-Zorrilla, J.M.; Fernandez-Calvo, P.; Zander, M.; Lewsey, M.G.; García-Casado, G.; FernándezBarbero, G.; Ecker, J.R.; Solano, R. JA-pathway MYC transcription factors regulate photomorphogenic responses by targeting HY5 gene expression. Plant J. 2020, 102, 138-152. [CrossRef] [PubMed]

107. Chen, X.; Yao, Q.; Gao, X.; Jiang, C.; Harberd, N.P.; Fu, X. Shoot-to-root mobile transcription factor HY5 coordinates plant carbon and nitrogen acquisition. Curr. Biol. 2016, 26, 640-646. [CrossRef]

108. van Gelderen, K.; Kang, C.; Paalman, R.; Keuskamp, D.; Hayes, S.; Pierik, R. Far-red light detection in the shoot regulates lateral root development through the HY5 transcription factor. Plant Cell 2018, 30, 101-116. [CrossRef] [PubMed]

109. Ji, Y.; Nuñez Ocaña, D.; Choe, D.; Larsen, D.H.; Marcelis, L.F.M.; Heuvelink, E. Far-red radiation stimulates dry mass partitioning to fruits by increasing fruit sink strength in tomato. New Phytol. 2020, 228, 1914-1925. [CrossRef]

110. Corrado, G.; Arena, S.; Araujo-Burgos, T.; Coppola, M.; Rocco, M.; Scaloni, A.; Rao, R. The expression of the tomato prosystemin in tobacco induces alterations irrespective of its functional domain. Plant Cell Tiss. Org. 2016, 125, 509-519. [CrossRef]

111. Tejeda-Sartorius, M.; Martínez de la Vega, O.; Délano-Frier, J.P. Jasmonic acid influences mycorrhizal colonization in tomato plants by modifying the expression of genes involved in carbohydrate partitioning. Physiol. Plant. 2008, 133, 339-353. [CrossRef] [PubMed]

112. De la Noval-Pons, B.M.; León-Díaz, O.; Martínez-Gallardo, N.A.; Pérez-Ortega, E.; Délano-Frier, J.P. Pattern of $\beta$-1, 3-glucanase and chitinase activity in the AMF-systemin interaction in tomato. I. Presymbiotic phase. Cult. Trop. 2017, $38,36-43$.

113. de la Noval-Pons, B.M.; León-Díaz, O.; Martínez-Gallardo, N.A.; Pérez-Ortega, E.; Délano-Frier, J.P. Activity pattern of $\beta$ 1,3-glucanases and quitinases in the AMF—systemin interaction in tomato. II Early symbiotic phase. Cult. Trop. 2017, 38, 84-91.

114. Ruiz-Segoviano, S.A. Efecto de la Sistemina y Otros Péptidos Afines en el Crecimiento de Plantas de Arabidopsis thaliana y Solanum lycopersicum Inoculadas con Rizobacterias Benéficas. Master's Thesis, Cinvestav-Irapuato, Irapuato, Mexico, 2021. 